\title{
Spatial variability of some soil properties varies in oil palm (Elaeis guineensis Jacq.) plantations of west coastal area of India
}

\author{
Sanjib Kumar Behera ${ }^{1}$, Kancherla Suresh ${ }^{1}$, Bezawada Narsimha Rao ${ }^{1}$, Ravi Kumar Mathur ${ }^{1}$, \\ Arvind Kumar Shukla ${ }^{2}$, Kamireddy Manorama ${ }^{1}$, Kummari Ramachandrudu ${ }^{1}$, Parasa Harinarayana ${ }^{1}$, and \\ Chandra Prakash ${ }^{2}$ \\ ${ }^{1}$ ICAR-Indian Institute of Oil Palm Research, Pedavegi, West Godavari, Andhra Pradesh 534450, India \\ ${ }^{2}$ ICAR-Indian Institute of Soil Science, Nabibagh, Berasia Road, Bhopal, Madhya Pradesh 462038, India \\ Correspondence to: Sanjib Kumar Behera (sanjibkumarbehera123@gmail.com)
}

Received: 14 January 2016 - Published in Solid Earth Discuss.: 28 January 2016

Revised: 31 May 2016 - Accepted: 6 June 2016 - Published: 28 June 2016

\begin{abstract}
Mapping spatial variability of soil properties is the key to efficient soil resource management for sustainable crop yield. Therefore, the present study was conducted to assess the spatial variability of soil properties such as acidity $(\mathrm{pH})$, salinity (electrical conductivity (EC)), organic carbon, available $\mathrm{K}$, available $\mathrm{P}$, exchangeable $\mathrm{Ca}^{2+}$, exchangeable $\mathrm{Mg}^{2+}$, available $\mathrm{S}$ and hot water soluble $\mathrm{B}$ in surface (0$20 \mathrm{~cm}$ ) and subsurface $(20-40 \mathrm{~cm})$ soil layers of oil palm plantations in south Goa district of Goa located in west coastal area of India. A total of 128 soil samples were collected from 64 oil palm plantations of Goa located at an approximate interval of $1-2 \mathrm{~km}$ and analyzed. Soil was acidic to neutral in reaction. Other soil properties varied widely in both the soil layers. Correlations between soil $\mathrm{pH}$ and exchangeable $\mathrm{Ca}^{2+}$, between soil EC and available $\mathrm{K}$, between available $\mathrm{P}$ and available $\mathrm{S}$ and between exchangeable $\mathrm{Ca}^{2+}$ and exchangeable $\mathrm{Mg}^{2+}$ in both the soil layers were found to be positive and significant $(P<0.01)$. Geostatistical analysis revealed a varied spatial distribution pattern for the measured soil properties. Best-fit models for measured soil properties were exponential, Gaussian, stable, K-Bessel and spherical with moderate to strong spatial dependency. The results revealed that site-specific fertilizer management options needed to be adopted in the oil palm plantations of the study area owing to variability in soil properties.
\end{abstract}

\section{Introduction}

Soil is the key part of the earth system which controls hydrological, biological, and geochemical cycles and it offers goods, resources and services to mankind (Keesstra et al., 2012; Smith et al., 2015; Decock et al., 2015; Brevik et al., 2015; Berendse et al., 2015). Un-sustainable soil management practices lead to soil degradation, which is a worldwide topic, mainly because of loss of soil organic matter (SOM), soil erosion, changes in soil structure, degradation of the biota in the soils and soil chemical degradation (Cerda et al., 2009; Mupenzi et al., 2011; Novara et al., 2013; Mukherjee et al., 2014; Lieskovský and Kenderessy, 2014; Stanchi et al., 2015; Seutloali and Beckedahl, 2015; Novara et al., 2015). Soil degradation along with natural processes results in degradation of coastal areas, which covers more than $10 \%$ of the earth surface area with 35,6000 and $7517 \mathrm{~km}$ coast line in world and India, respectively (Misdorp, 1990; Sanil Kumar et al., 2006).

Geographical distribution maps of soil properties, obtained from soil surveys, help in correct management of soil nutrients (Brevik et al., 2016). These maps are required to understand the patterns and processes of soil spatial variability, which is the combined effect of soil physical, chemical and biological processes operating at different spatiotemporal scales combined with anthropogenic activities (Goovaerts, 1998). Geostatistical tools are useful in preparation of the maps based on limited number of samples collected from agricultural landscapes. Kriging simulation technique predicts the values at un-sampled locations by spatial correlation and reduces variance of estimation error and investigation costs (Saito et al., 2005; Pereira et al., 2015). Spatial variability of soil properties is assessed effectively by geostatistical methods (Mueller et al., 2003; Pereira et al., 2013; 
Ochoa-Cueva et al., 2015) for site-specific management of nutrients through variable rate fertilizer application to avoid over and under application of nutrients (Fu et al., 2010). Information regarding variability of soil properties in soil profile is helpful to assess the contribution of subsurface soil layers to crop nutrition and potential capacity of the soil to supply nutrients during crop growth. It also helps in understanding the effect of different management practices, under a given cropping system, on the downward movement as well as recycling of nutrients to the surface layers (Behera and Shukla, 2013; Parras-Alcantara et al., 2015).

Oil palm (Elaeis guineensis Jacq.) is a high-oil-yielding crop compared to annual oil crops (Johnston et al., 2009; Murphy, 2009). Oil palm uses about 162, 30, 217, 38 and $36 \mathrm{~kg}$ of $\mathrm{N}, \mathrm{P}, \mathrm{K}, \mathrm{Mg}$ and $\mathrm{Caha}^{-1}$ year $^{-1}$, respectively, to produce $2.5 \mathrm{Mg}$ of oil ha ${ }^{-1}$ year $^{-1}$ (Mengel and Kirkby, 1987). Considering oil to bunch ratio of $1: 4,2.5 \mathrm{Mg}$ oil ha $^{-1}$ is equivalent to $10 \mathrm{Mg} \mathrm{FFB} \mathrm{ha}^{-1}$ year $^{-1}$, but average FFB yield in well-managed plantations is much higher (Narsimha Rao et al., 2014). Nutrient content in $1 \mathrm{Mg}$ of FFB obtained from Dura palms is 2.94, 0.44, 3.71, 0.77, $0.81 \mathrm{~kg}$ of N, P, K, $\mathrm{Mg}$ and $\mathrm{Ca}$, respectively, whereas $\mathrm{Mn}, \mathrm{Fe}, \mathrm{B}, \mathrm{Cu}$ and $\mathrm{Zn}$ content per $1 \mathrm{Mg}$ of FFB is $1.51,2.47,2.15,4.76$ and $4.93 \mathrm{~g}$, respectively (Ng and Thamboo, 1967). Calibrated soil and leaf analysis helps in effective fertilizer recommendations in most of the crops (Smith and Loneragan, 1997; McLaughlin et al., 1999). In oil palm, leaf nutrient analysis is commonly used for estimating fertilizer requirement (Fairhurst and Mutert, 1999; Corley and Tinker, 2003). The relationship between leaf analysis and palm productivity is generally evident, and an assessment of fertilizer needs can be based on such an analysis. However for a cost-effective approach, leaf analysis has to be integrated with soil analysis (Goh et al., 2003). It is therefore pertinent to assess soil nutrient status for effective and sustainable fertilizer management programme in oil palm.

Prasad et al. (2013) reported wide range in quantity of fertilizer applied indicating that oil palms were either underfertilized or over-fertilized. Also, low cost and high availability of some fertilizers have encouraged farmers to make excessive applications with the belief that high yields would be ensured. However, this management adversely affects soil fertility, productivity, fruit quality and ground water quality. Different amount of fertilizer application to different soil types may alter soil properties. It is therefore pertinent for the farmers to economize on fertilizer adopting a strategy for site-specific and/or area-specific management based on spatial variability of soil properties to make oil palm production environmentally sustainable and economically viable. Spatial variability of soil properties in oil palm plantations have to be carefully evaluated to implement sustainable soil management practices. Thus, the present study was carried out in soils of oil palm plantations south Goa district of India with the following objectives, (i) to estimate the spatial variability of some soil properties through semivariogram anal-

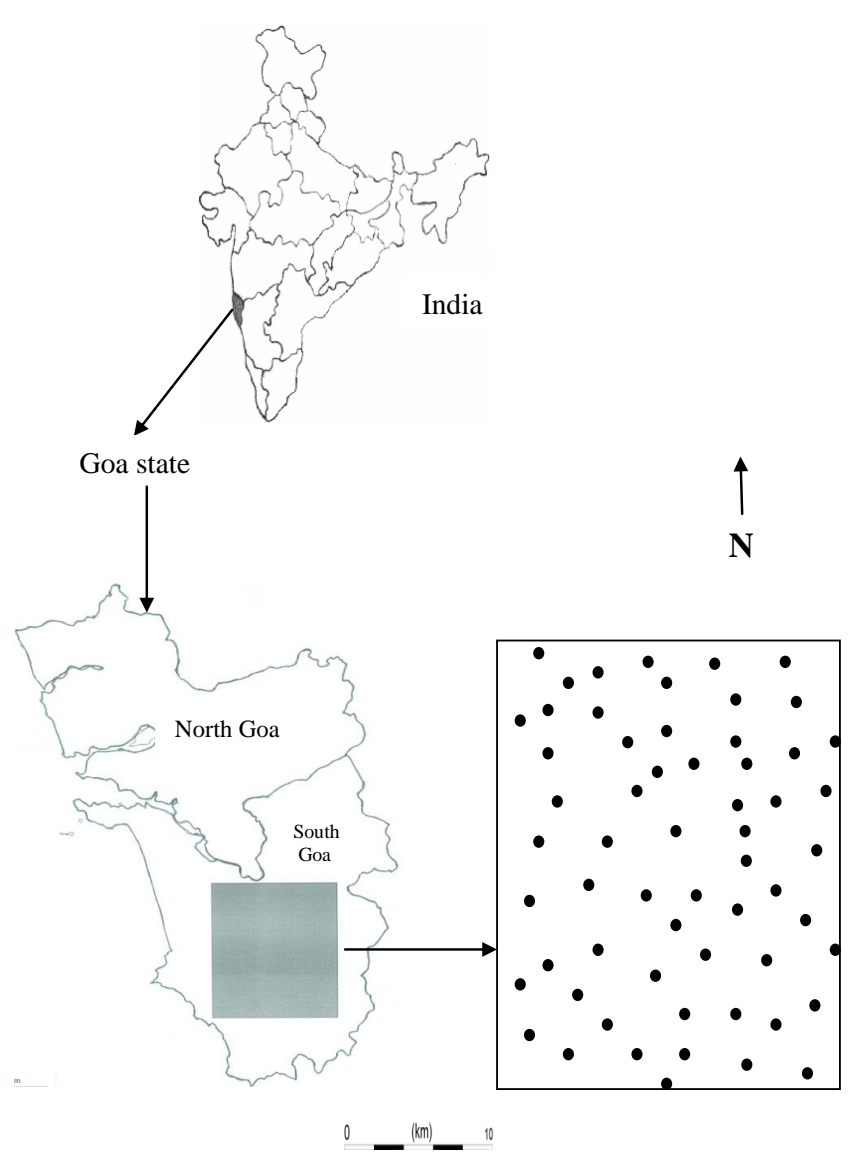

Figure 1. Spatial distribution of sampling points in south Goa district of Goa state (western India).

ysis, (ii) to assess the relationship among the estimated soil properties and (iii) to develop spatial maps for soil properties using the parameters of the best fitted semivariogram model and interpolation using ordinary kriging technique.

\section{Material and methods}

\subsection{Study site}

A survey was carried out in south Goa district of Goa state of India during 2012-2013 to find out soil and plant nutritional status in randomly selected 64 tenera oil palm plantations (with 5 to 21 years of age) (Fig. 1). Oil palm is cultivated in an area of approximately 1000 ha which is $1 \%$ of agricultural land in the state. The state lies between $15^{\circ} 6.8^{\prime} 96$ to $15^{\circ} 41.7^{\prime} 26 \mathrm{~N}$ latitudes and $74^{\circ} 76^{\prime} 60^{\prime \prime}$ to $73^{\circ} 56^{\prime} 78^{\prime \prime} \mathrm{E}$ longitudes with altitude ranging from 4 to $90 \mathrm{~m}$ a.s.l. The climate of the area is tropical monsoon type. Hot and humid climate prevails for most of the year. Annual mean rainfall (average of 30 years) is $2926 \mathrm{~mm}$, concentrated from early June to late September. On average, May is the warmest month, with temperature peaks over $35^{\circ} \mathrm{C}$ and relative humidity of 
$70 \%$. Goa experiences short winter seasons between midDecember and February and these months are marked by mean night temperature of approximately $21^{\circ} \mathrm{C}$ and a mean day temperature of around $28^{\circ} \mathrm{C}$ with relative humidity of $65 \%$. According to Bhattacharyya et al. (2013), the main soils in the study area are Inceptisols, Ultisols, Entisols and Alfisols (classified as in Soil Survey Staff, 2014), sandy loam to silty loam texture, developed from granite, granite-gneiss, quartzite/schistose and basalt.

\subsection{Soil sampling, processing and analysis}

A total of 128 soil samples i.e., 64 from 0 to $20 \mathrm{~cm}$ (surface) and 64 from 20 to $40 \mathrm{~cm}$ (subsurface) depths were collected at random points inside $3 \mathrm{~m}$ radius from the palm during the survey to assess soil properties of oil palm plantations at an approximate interval of 1 to $2 \mathrm{~km}$. Five soil samples were collected at random from each sampling location within a radius of approximately $60 \mathrm{~cm}$ using a hand auger. The five samples were then mixed to obtain the representative soil sample of the sampling point. The latitude, longitude, and elevation at each sampling point were recorded using a handheld global positioning system (GPS). The soil samples were dried at room temperature $\left(25 \pm 3^{\circ} \mathrm{C}\right)$. Stone and debris from samples were removed and then ground to pass a $2 \mathrm{~mm}$ sieve. The processed soil samples were tested for acidity $(\mathrm{pH})$, salinity (EC), organic carbon (OC) content, available $\mathrm{K}$ ( $\left.\mathrm{NH}_{4} \mathrm{OAc}-\mathrm{K}\right)$, available $\mathrm{P}$ (Bray's P-1) (Bray's-P), exchangeable $\mathrm{Ca}^{2+}\left(\right.$ Exch. $\left.\mathrm{Ca}^{2+}\right)$, exchangeable $\mathrm{Mg}^{2+}$ (Exch. $\left.\mathrm{Mg}^{2+}\right)$, available $\mathrm{S}\left(\mathrm{CaCl}_{2}-\mathrm{S}\right)$ and hot water extractable $\mathrm{B}$ (HWB). Determination of soil $\mathrm{pH}$ and EC (1:2 soil water ratio $(w / v)$ suspension) were carried out using $\mathrm{pH}$-meter and conductivity meter (Jackson, 1973). Walkley-Black method (Walkley and Black, 1934) was followed for assessing soil OC content. $\mathrm{NH}_{4} \mathrm{OAc}-\mathrm{K}$ was estimated after extracting soil samples with neutral $1 \mathrm{~N}$ ammonium acetate solution (Hanway and Heidel, 1952) followed by flame photometry estimation. Available P was extracted using Bray's P-1 reagent (Bray and Kurtz, 1945) and estimated through spectrophotometry. Exchangeable $\mathrm{Ca}^{2+}$ and $\mathrm{Mg}^{2+}$ were extracted using neutral normal ammonium acetate solution (Jones, 1998) and estimated through atomic absorption spectrometry. Available $\mathrm{S}$ was estimated by the turbidity method (Williams and Steinbergs, 1969). HWB content was estimated through Azomethine-H reagent (Gupta, 1967) using spectrophotometry.

\subsection{Statistical and geostatistical analysis}

The descriptive statistics like minimum, maximum, mean, standard deviation (SD), coefficient of variation (CV), and skewness for soil properties were computed using the SAS 9.2 software pack (SAS, 2011). Relationship among the studied soil properties were established using Pearson's corre- lation coefficient analysis. Significant differences were observed at $P<0.05$.

ArcMap 10.1 (ESRI, 2012) was used to analyze the spatial structure of soil properties. Before using geostatistics, normality of data distribution was checked by Shapiro-Wilk test at $5 \%$ (Shapiro and Wilk, 1965). Soil properties like $\mathrm{pH}$ and $\mathrm{OC}$ content in both the soil layers and $\mathrm{CaCl}_{2}-\mathrm{S}$ content in subsurface soil layers exhibited normal distribution (Table 1). While, data transformation to normal distribution was carried out for rest of the soil properties. Prior to geostatistical analyses, the data were examined for the presence of trend (by "Geostatistical analyst" of ArcGIS 10.1) and removed (by fitting to second order polynomial). According to McCormick et al. (2009), trend in the variation signals a departure from the intrinsic hypothesis in which the process is assumed to be random and it violates the assumptions on which geostatistics is based on. By removing the trend, it will be possible to more accurately model the variation because the trend will not be influencing the spatial analysis (Kerry and Oliver, 2007). The semivariogram was used to measure spatial variability of soil properties and to obtain input parameters for the kriging method of spatial interpolation (Goovaerts, 1997; Tesfahunegn et al., 2011). It is half of the expected squared difference between paired data values to the lag distance by which locations are separated. The experimental semivariograms of soil properties were derived as described below.

$\gamma(h)=\frac{1}{2 m(h)} \sum_{i=1}^{m(h)}\left[Z\left(X_{i}+h\right)-Z\left(X_{i}\right)\right]^{2}$

Where $\gamma(h)$ is the experimental semivariogram, $h$ is the lag, $m(h)$ is number of sample value pairs separated by $h, Z\left(X_{i}\right)$, $Z\left(X_{i}+h\right)$ are sample values at two points at $X_{i}$ and $\left(X_{i}+\right.$ $h)$ locations, respectively. The distance between the sample pairs is rarely equal to $h$ in irregular sampling and $h$ is often represented by a distance interval.

Semivariogram parameters like nugget/sill ratio and range were obtained for soil properties. The nugget/sill ratio was used to classify the spatial dependence of variables (Oliver and Webster, 2014). Ratio values less than or equal to 0.25 , between 0.25 and 0.75 , more than 0.75 were considered strongly, moderately and weakly spatially dependent, respectively (Behera et al., 2011). Best-fit semivariograms models were selected by cross-validation technique. Mean square error (MSE) was estimated to predict the accuracy of models (Utset et al., 2000).

$\mathrm{MSE}=\frac{\sum_{i=1}^{n}\left[z\left(x_{i}, y_{i}\right)-z \cdot\left(x_{i}, y_{i}\right)\right]^{2}}{n}$

Goodness-of-prediction criterium $\mathrm{G}$ is one of the methods used for accuracies of interpolated maps (Agterberg, 1984; Tesfahunegn et al., 2011). Accuracies of interpolated maps of studied soil properties were checked by $G$ values. According to Parfitt et al. (2009), positive $G$ values indicate that the map 
Table 1. Soil properties of surface $(0-20 \mathrm{~cm})$ and subsurface $(20-40 \mathrm{~cm})$ layers $(n=64$ at each case).

\begin{tabular}{|c|c|c|c|c|c|c|c|}
\hline Variable & Soil layer & Mean \pm SD & $\mathrm{CV}(\%)$ & Minimum & Maximum & Skewness & Distribution \\
\hline \multirow[t]{2}{*}{$\mathrm{pH}$} & Surface & $5.35 \pm 0.45$ & 8.64 & 4.25 & 6.77 & 0.18 & Normal \\
\hline & Subsurface & $5.28 \pm 0.46$ & 8.63 & 4.53 & 6.52 & 0.65 & Normal \\
\hline \multirow[t]{2}{*}{$\mathrm{EC}$} & Surface & $0.13 \pm 0.17$ & 125 & 0.05 & 1.06 & 4.06 & Transformed \\
\hline & Subsurface & $0.08 \pm 0.06$ & 75.3 & 0.03 & 0.41 & 3.02 & Transformed \\
\hline \multirow[t]{2}{*}{$\mathrm{OC}$} & Surface & $19.8 \pm 8.77$ & 44.4 & 5.07 & 48.4 & 0.83 & Normal \\
\hline & Subsurface & $13.2 \pm 7.33$ & 55.5 & 1.95 & 31.2 & 0.75 & Normal \\
\hline \multirow[t]{2}{*}{$\mathrm{NH}_{4} \mathrm{OAc}-\mathrm{K}$} & Surface & $270 \pm 29.9$ & 88.7 & 58.1 & 1167 & 1.80 & Transformed \\
\hline & Subsurface & $199 \pm 165$ & 82.8 & 16.1 & 856 & 2.16 & Transformed \\
\hline \multirow[t]{2}{*}{ Bray's-P } & Surface & $24.7 \pm 3.39$ & 127 & 0.86 & 141 & 2.14 & Transformed \\
\hline & Subsurface & $9.78 \pm 13.2$ & 135 & 0.90 & 42.3 & 2.52 & Transformed \\
\hline \multirow[t]{2}{*}{ Exch. $\mathrm{Ca}^{2+}$} & Surface & $914 \pm 588$ & 64.3 & 200 & 2997 & 1.56 & Transformed \\
\hline & Subsurface & $795 \pm 724$ & 91.1 & 194 & 5177 & 3.89 & Transformed \\
\hline \multirow[t]{2}{*}{ Exch. $\mathrm{Mg}^{2+}$} & Surface & $203 \pm 141$ & 69.3 & 36.0 & 744 & 1.75 & Transformed \\
\hline & Subsurface & $225 \pm 156$ & 69.4 & 24.0 & 720 & 1.27 & Transformed \\
\hline \multirow[t]{2}{*}{$\mathrm{CaCl}_{2}-\mathrm{S}$} & Surface & $23.2 \pm 16.4$ & 70.7 & 3.00 & 87.7 & 1.60 & Transformed \\
\hline & Subsurface & $16.3 \pm 10.1$ & 62.0 & 1.50 & 43.5 & 0.93 & Normal \\
\hline \multirow[t]{2}{*}{ HWB } & Surface & $0.70 \pm 0.38$ & 54.7 & 0.09 & 2.10 & 1.43 & Transformed \\
\hline & Subsurface & $0.64 \pm 0.44$ & 68.6 & 0.04 & 2.56 & 1.70 & Transformed \\
\hline
\end{tabular}

$\mathrm{SD}$ - standard deviation; $\mathrm{CV}$ - coefficient of variation; $\mathrm{EC}$ - electrical conductivity, $\mathrm{dS} \mathrm{m}^{-1}$; OC - organic carbon, $\mathrm{g} \mathrm{kg}^{-1} ; \mathrm{NH}_{4} \mathrm{OAc}-\mathrm{K}$, $\mathrm{mg} \mathrm{kg}^{-1}$; Bray's-P, mg kg${ }^{-1}$; exch. $\mathrm{Ca}^{2+}, \mathrm{mg} \mathrm{kg}^{-1}$; exch. $\mathrm{Mg}^{2+}, \mathrm{mg} \mathrm{kg}^{-1} ; \mathrm{CaCl}_{2}-\mathrm{S}, \mathrm{mg} \mathrm{kg}^{-1} ; \mathrm{HWB} \mathrm{mg} \mathrm{kg}^{-1}$.

obtained by interpolating data from the samples is more accurate than a catchment average. Negative and close to zero $G$ values indicate that the catchment-scale average predicts the values at unsampled locations as accurately as or even better than the sampling estimates. Ordinary kriging interpolation was carried out to develop spatial distribution maps for soil properties.

\section{Results and discussion}

\subsection{Descriptive statistics of soil properties}

The descriptive statistics revealed considerable variability of soil properties in both surface and subsurface soil layers of oil palm plantations (Table 1). The mean values of soil properties were $5.35,0.13 \mathrm{dS} \mathrm{m}^{-1}, 19.8 \mathrm{~g} \mathrm{~kg}^{-1}, 270 \mathrm{mg} \mathrm{kg}^{-1}$, $24.7 \mathrm{mg} \mathrm{kg}^{-1}, 914 \mathrm{mg} \mathrm{kg}^{-1}, 203 \mathrm{mg} \mathrm{kg}^{-1}, 23.2 \mathrm{mg} \mathrm{kg}^{-1}$ and $0.70 \mathrm{mg} \mathrm{kg}^{-1}$ for $\mathrm{pH}$, EC, OC, $\mathrm{NH}_{4} \mathrm{OAc}-\mathrm{K}$, Bray's-P, exchangeable $\mathrm{Ca}^{2+}$, exchangeable $\mathrm{Mg}^{2+}, \mathrm{CaCl}_{2}-\mathrm{S}$ and $\mathrm{HWB}$, respectively, in surface soil layers. Whereas the mean values were $5.28,0.08 \mathrm{dS} \mathrm{m}^{-1}, 13.2 \mathrm{~g} \mathrm{~kg}^{-1}, 199 \mathrm{mg} \mathrm{kg}^{-1}$, $9.78 \mathrm{mg} \mathrm{kg}^{-1}, 795 \mathrm{mg} \mathrm{kg}^{-1}, 225 \mathrm{mg} \mathrm{kg}^{-1}, 16.3 \mathrm{mg} \mathrm{kg}^{-1}$ and $0.64 \mathrm{mg} \mathrm{kg}^{-1}$ for $\mathrm{pH}$, EC, OC, $\mathrm{NH}_{4} \mathrm{OAc}-\mathrm{K}$, Bray's-P, exchangeable $\mathrm{Ca}^{2+}$, exchangeable $\mathrm{Mg}^{2+}, \mathrm{CaCl}_{2}-\mathrm{S}$ and $\mathrm{HWB}$, respectively, in subsurface soil layers. The values of $\mathrm{CV}$ for soil properties ranged from 8.63 to $135 \%$. The values of $\mathrm{CV}$ for soil $\mathrm{pH}$ in both the soil layers revealed their low variability $(\mathrm{CV}<25 \%)$. The rest of the soil properties exhibited moderate (CV 25-75\%) variability except salinity, $\mathrm{NH}_{4} \mathrm{OAc}-\mathrm{K}$ and Bray's-P in both the soil layers and ex- changeable $\mathrm{Ca}^{2+}$ in subsurface soil layers, which had high $(\mathrm{CV}>75 \%)$ variability. Low $\mathrm{CV}$ values for soil $\mathrm{pH}$ was due to transformed measurement of hydrogen ion concentration. Skewness values of 0.18 to 3.89 for different soil proprieties revealed that some soil properties were not normally distributed. This variation and non-normal distribution of soil properties in the studied areas may be due to adoption of different soil management practices including variation in fertilizer application and other crop management practices (Tesfahunegn et al., 2011; Srinivasarao et al., 2014; Ferreira et al., 2015).

The mean values of soil $\mathrm{pH}$ were acidic in both surface (5.35) and subsurface (5.28) soil layers (Table 1). The acidic nature of soil in the studied area may be due to acidic parent material and prevailing rainfall pattern. The values of soil EC indicate the non-saline nature of soils. Soil OC contents varied widely in both surface and subsurface soil layers. Principal reason for variation in soil OC content may be due to adoption of different cultural practices including addition of crop biomass to the soils. Surface soil layers had slightly higher OC content (mean value $19.8 \mathrm{~g} \mathrm{~kg}^{-1}$ ) than OC content in subsurface soil layers (mean value $13.2 \mathrm{~g} \mathrm{~kg}^{-1}$ ). Surface soil layers had higher $\mathrm{NH}_{4} \mathrm{OAc}-\mathrm{K}$, Bray's-P, $\mathrm{CaCl}_{2}-\mathrm{S}$ and HWB content compared to that in subsurface soil layers (Table 1). The content of these nutrients varied greatly among the soils because of heterogeneity in fertilizer application in the area. The mean values of exchangeable $\mathrm{Ca}^{2+}$ were 914 and $795 \mathrm{mg} \mathrm{kg}^{-1}$ for surface and subsurface soil layers, respectively, whereas surface soil layers were having 203 and $225 \mathrm{mg} \mathrm{kg}^{-1}$ of mean exchangeable $\mathrm{Mg}^{2+}$ content, 
Table 2. Pearson's correlation coefficients between soil properties at the surface $(0-20 \mathrm{~cm})$ and subsurface $(20-40 \mathrm{~cm})$ layers. Only significant coefficients are shown $(*, p<0.05 ; * *, p<0.01)(n=64)$.

\begin{tabular}{|c|c|c|c|c|c|c|}
\hline Layer & & $\mathrm{pH}$ & $\mathrm{EC}$ & $\mathrm{OC}$ & Bray's-P & Exch. $\mathrm{Ca}^{2+}$ \\
\hline Surface & $\begin{array}{l}\mathrm{NH}_{4} \mathrm{OAc}-\mathrm{K} \\
\text { Bray's-P } \\
\text { Exch. } \mathrm{Ca}^{2+} \\
\text { Exch. } \mathrm{Mg}^{2+} \\
\mathrm{CaCl}_{2}-\mathrm{S} \\
\mathrm{HWB}\end{array}$ & $0.67 * *$ & $0.45^{* *}$ & $\begin{array}{l}0.26^{*} \\
0.30^{*}\end{array}$ & $0.44 * *$ & $0.37 * *$ \\
\hline Subsurface & $\begin{array}{l}\mathrm{NH}_{4} \mathrm{OAc}-\mathrm{K} \\
\text { Bray's-P } \\
\text { Exch. } \mathrm{Ca}^{2+} \\
\text { Exch. } \mathrm{Mg}^{2+} \\
\mathrm{CaCl}_{2}-\mathrm{S}\end{array}$ & $0.42 * *$ & $\begin{array}{l}0.48^{* *} \\
0.32^{*}\end{array}$ & & $0.36 * *$ & $0.33^{* *}$ \\
\hline
\end{tabular}

EC - electrical conductivity, $\mathrm{dS} \mathrm{m}^{-1}$; OC - organic carbon, $\mathrm{g} \mathrm{kg}^{-1} ; \mathrm{NH}_{4} \mathrm{OAc}-\mathrm{K}, \mathrm{mg} \mathrm{kg}^{-1} ; \mathrm{Bray}^{\prime} \mathrm{s}-\mathrm{P}, \mathrm{mg} \mathrm{kg}^{-1}$; exch. $\mathrm{Ca}^{2+}, \mathrm{mg} \mathrm{kg}^{-1}$; exch. $\mathrm{Mg}^{2+}, \mathrm{mg} \mathrm{kg}^{-1} ; \mathrm{CaCl}_{2}-\mathrm{S}, \mathrm{mg} \mathrm{kg}^{-1} ; \mathrm{HWB}, \mathrm{mg} \mathrm{kg}^{-1}$.

respectively. Other studies reported similar results highlighting different distribution pattern of soil properties, primary, secondary and micronutrients under different soil-crop management situations (Franzlubbers and Hons, 1996; Sharma et al., 2005; Behera and Shukla, 2013).

\subsection{Relationship among soil properties}

The exchangeable $\mathrm{Ca}^{2+}$ content increased significantly with soil pH (Table 2). Behera and Shukla (2015) also recorded a positive and significant relationship of soil $\mathrm{pH}$ and soil OC with $\mathrm{K}$, exchangeable $\mathrm{Ca}^{2+}$ and exchangeable $\mathrm{Mg}^{2+}$ content in some cropped acid soils of India. Soil OC content in surface layers was positively and significantly correlated with exchangeable $\mathrm{Ca}^{2+}$ and HWB $(P<0.05)$. Most of the soil properties which influence nutrient storage and availability to plants are influenced by SOM type and content (Foth and Turk, 1972). Increased soil EC content led to higher $\mathrm{NH}_{4} \mathrm{OAc}-\mathrm{K}$ in both soil layers $(P<0.01)$, and higher $\mathrm{CaCl}_{2}-\mathrm{S}$ in surface layer and Bray's-P in subsurface layer $(P<0.05)$. Soil EC does not directly affect plant growth but has been used as an indirect indicator of the amount of nutrients available for plant uptake and salinity levels (Corwin and Lesch, 2005). EC has been used as a surrogate measure of salt concentration, organic matter, cation-exchange capacity, soil texture, soil thickness, nutrients, water-holding capacity, and drainage conditions. In site-specific management and high-intensity soil surveys, EC is used to partition units of management, differentiate soil types, and predict soil fertility and crop yields (Corwin and Lesch, 2005).

\subsection{Spatial structure and distribution of soil properties}

The best-fitted semivariograms for studied soil properties are depicted in Fig. 2, whereas their parameters are given in Table 3. The best fit models were exponential, Gausian, sta- ble, exponential, K-Bessel and circular for different soil layers. The value of nugget varied widely for soil properties. It was highest for exchangeable $\mathrm{Ca}^{2+}$ and the lowest for soil $\mathrm{pH}$. A higher nugget value indicates that the selected sampling distance could not capture well the spatial dependence, whereas lower nugget value reveals low spatial variability within small distances. Our findings are in line with the observations made by Tesfahunegn et al. (2011).

The nugget/sill ratio values ranged from 0.00 to 0.70 with strong (for surface $\mathrm{pH}$, subsurface $\mathrm{EC}$, and both surface and subsurface exchangeable $\mathrm{Ca}^{2+}$ ) to moderate (for rest soil properties) spatial dependency for the soil properties. Moderate to strong spatial dependence of soil properties are ascribed to intrinsic factors (such as mineralogy) as well as extrinsic factors including fertilization and other crop management practices (Cambardella et al., 1994). The range of the semivariogram is the maximum distance over which the soil properties of two samples are related. This can be an effective criterion for the evaluation of sampling design and the mapping of soil properties (Utset et al., 2000; Zhang et al., 2015). The range values of soil properties ranged from 878 to $4244 \mathrm{~m}$ (Table 3). Samples separated by distances lower than the range are spatially related, whereas those separated by a distance greater than the range are considered not to be spatially related. The soil sampling distance in the range of 1 to $2 \mathrm{~km}$ in this study was close with models range value. Level of similarity or disturbance of soil condition can be assessed by spatial dependency. A large range indicates that the value of measured soil property is influenced more by natural and anthropogenic factors over great distances than properties having smaller ranges (Lopez-Granados et al., 2002). Thus, a range value of about 4244 for $\mathrm{CaCl}_{2}-\mathrm{S}$ in the study region indicates that the measured values can be influenced over great distances comparison with other soil properties having smaller ranges. This is in agreement with the find- 
$\mathrm{pH}$

Surface

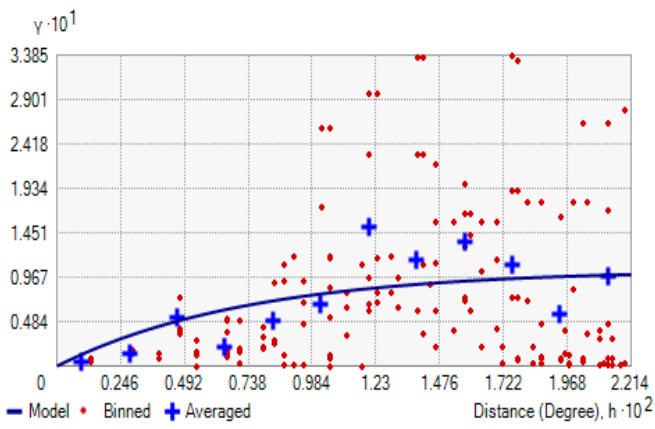

Surface

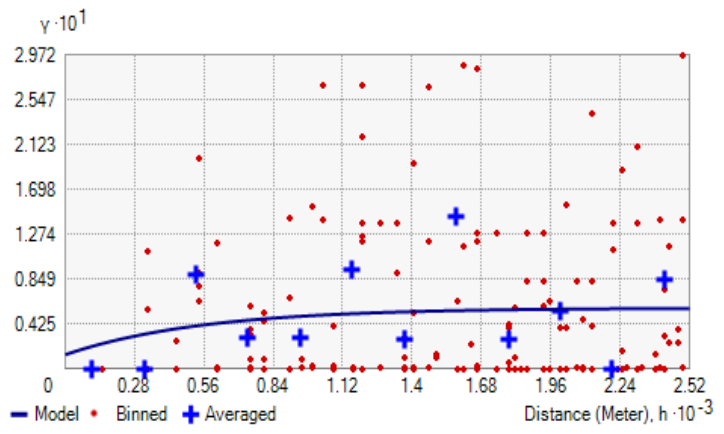

Surface

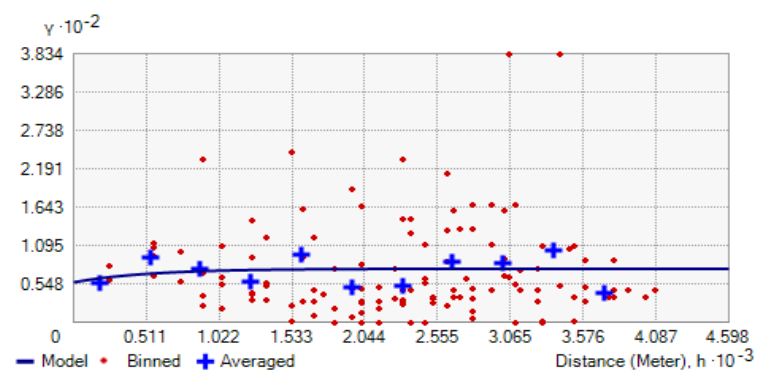

Surface

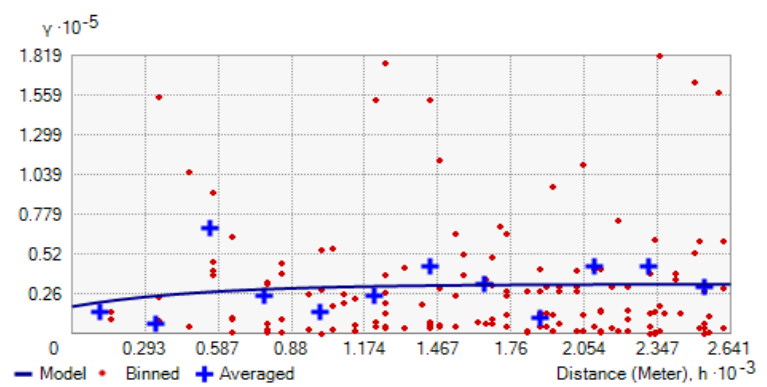

Subsurface

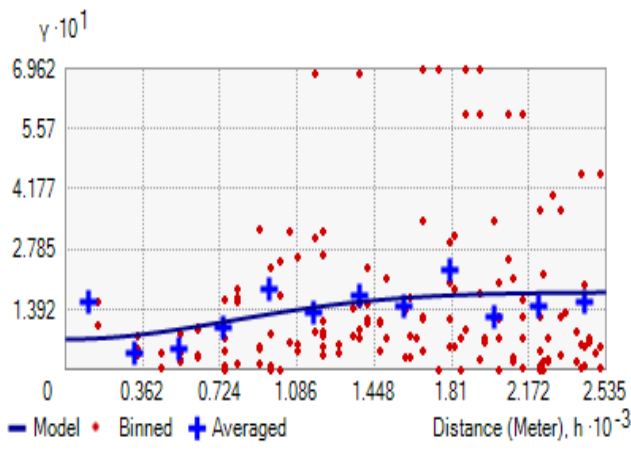

Subsurface

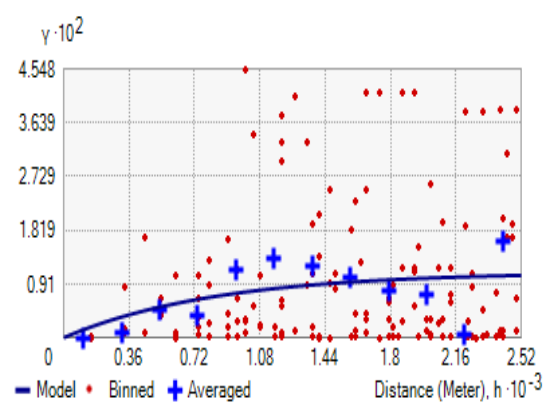

Subsurface

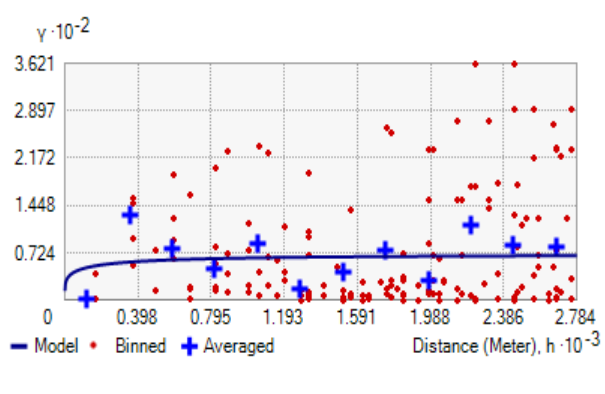

Subsurface

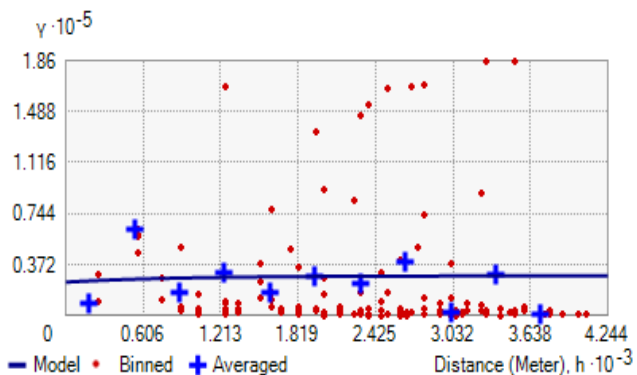

Figure 2. 


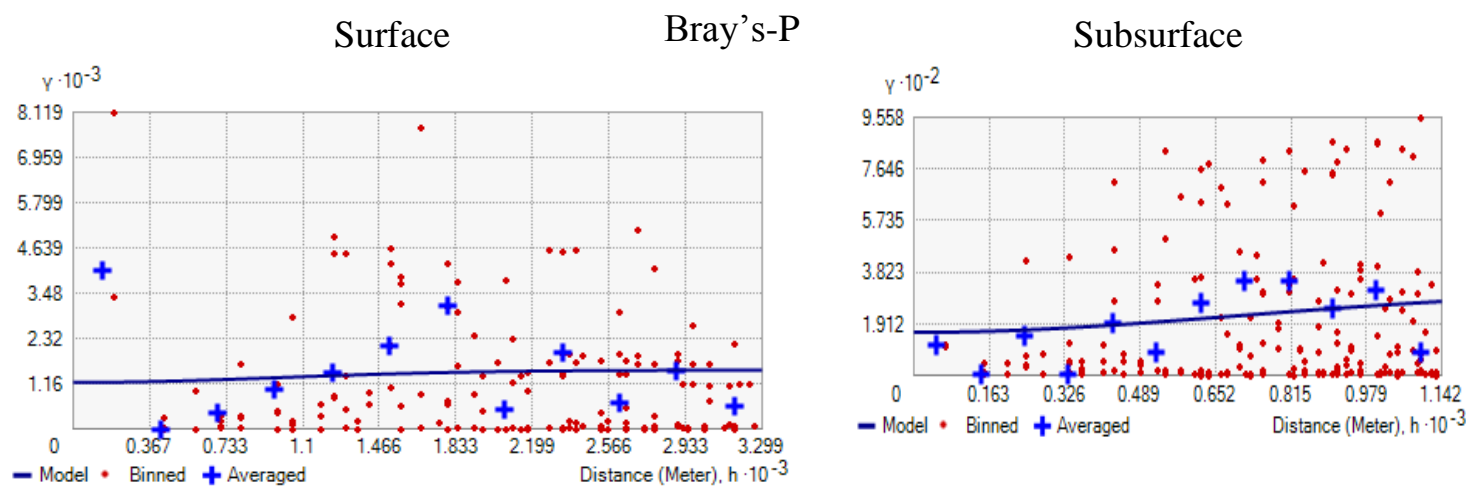

Exch. $\mathrm{Ca}^{2+}$

Surface

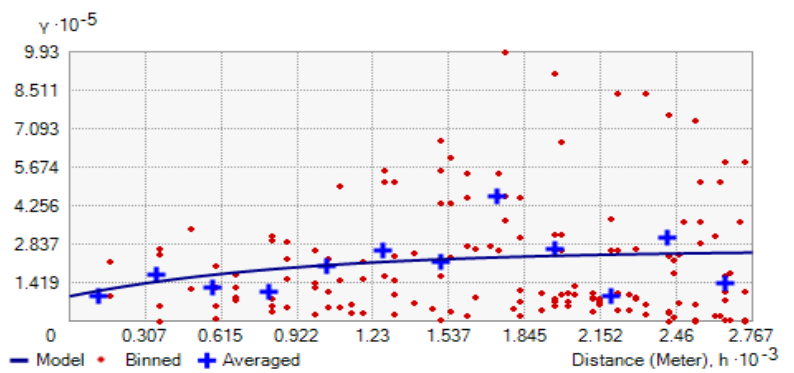

Surface

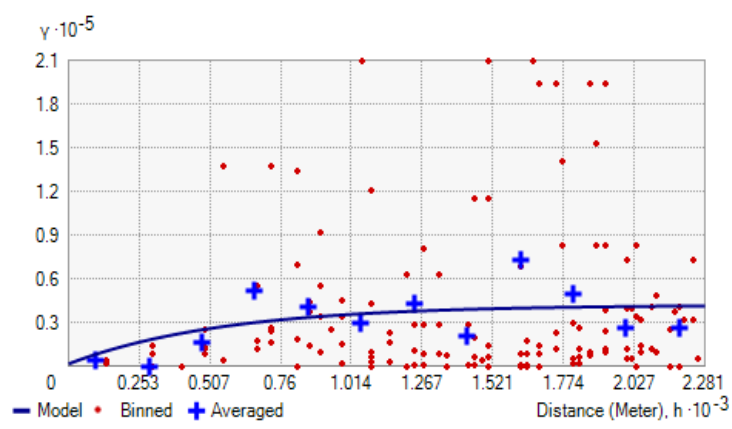

Surface

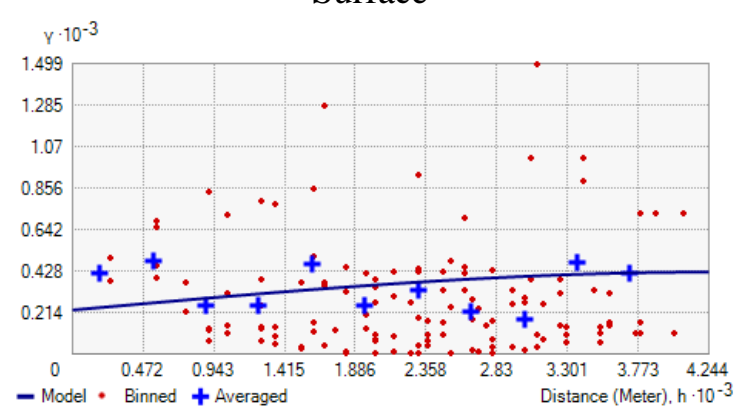

Subsurface

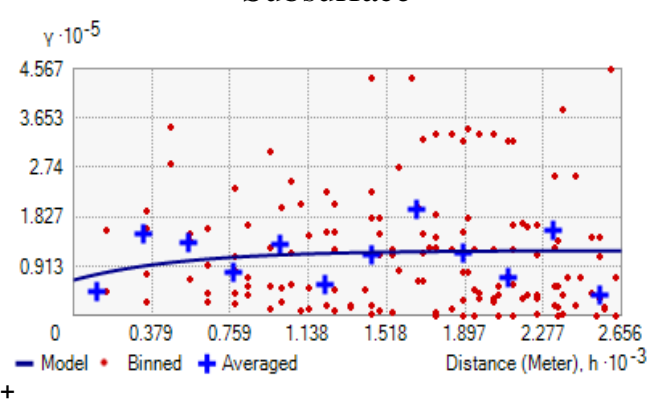

Subsurface

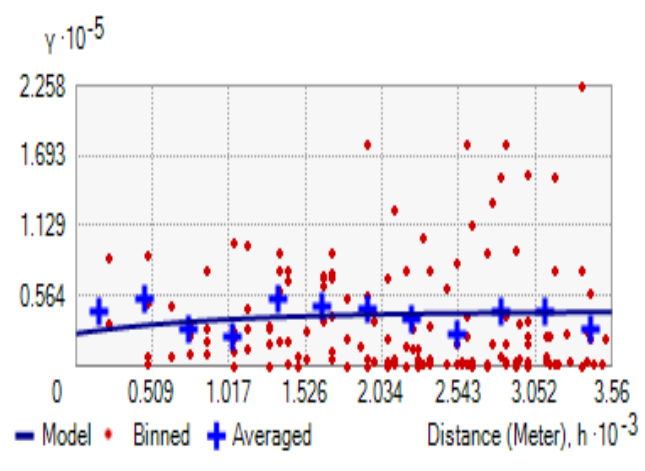

Subsurface

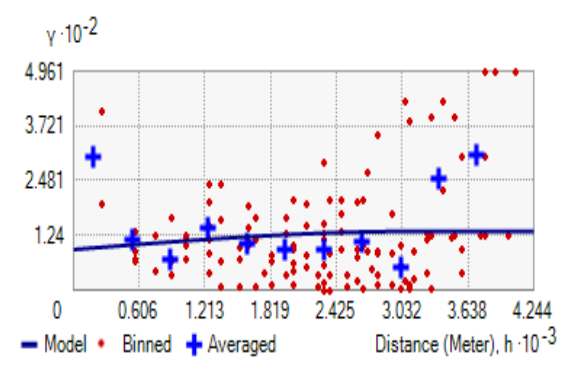

Figure 2. 


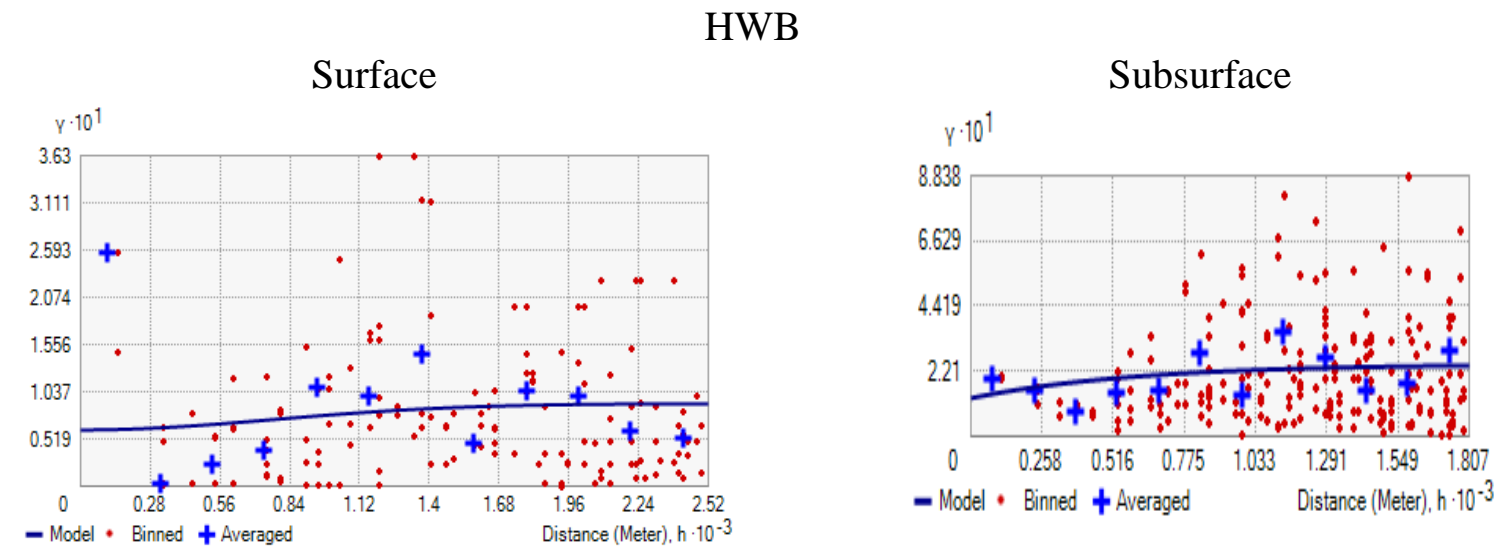

Figure 2. Semivariograms of soil properties in surface $(0-20 \mathrm{~cm})$ and subsurface $(20-40 \mathrm{~cm})$ soil layers.

Table 3. Semivariogram parameters of soil properties of studied areas.

\begin{tabular}{|c|c|c|c|c|c|c|c|c|c|c|}
\hline Variable & Soil layer & Model & Nugget & Sill & $\begin{array}{l}\text { Nugget: } \\
\text { sill ratio }\end{array}$ & $\begin{array}{l}\text { Spatial } \\
\text { class }\end{array}$ & $\begin{array}{l}\text { Range } \\
(\mathrm{m})\end{array}$ & $\begin{array}{l}\text { Obs. vs. } \\
\text { est. }\end{array}$ & MSE & $\begin{array}{l}\mathrm{G} \\
(\%)\end{array}$ \\
\hline \multirow[t]{2}{*}{$\mathrm{pH}$} & Surface & Exponential & 0.00 & 10 & 0.00 & Strong & 2367 & 0.915 & 0.61 & 54 \\
\hline & Subsurface & Gaussian & 0.06 & 0.18 & 0.33 & Moderate & 1892 & 0.888 & 0.52 & 53 \\
\hline \multirow[t]{2}{*}{$\mathrm{EC}$} & Surface & Stable* & 0.02 & 0.06 & 0.33 & Moderate & 1656 & 0.892 & 0.00 & 48 \\
\hline & Subsurface & Exponential* & 0.00 & 0.01 & 0.00 & Strong & 2519 & 0.953 & 0.00 & 43 \\
\hline \multirow[t]{2}{*}{$\mathrm{OC}$} & Surface & K-Bessel & 44.1 & 93.61 & 0.47 & Moderate & 1579 & 0.961 & 1.56 & 35 \\
\hline & Subsurface & Stable & 14.36 & 69.4 & 0.21 & Strong & 1579 & 0.943 & 1.89 & 51 \\
\hline \multirow[t]{2}{*}{$\mathrm{NH}_{4} \mathrm{OAc}-\mathrm{K}$} & Surface & Exponential* & 17546 & 32272 & 0.54 & Moderate & 1697 & 0.912 & 31.3 & 55 \\
\hline & Subsurface & Exponential* & 17568 & 35786 & 0.49 & Moderate & 1697 & 0.855 & 22.6 & 47 \\
\hline \multirow[t]{2}{*}{ Bray's-P } & Surface & Gaussian* & 1193 & 1708 & 0.70 & Moderate & 2401 & 0.981 & 22.9 & 48 \\
\hline & Subsurface & K-Bessel* & 159.43 & 323 & 0.49 & Moderate & 878 & 0.915 & 22.6 & 39 \\
\hline \multirow[t]{2}{*}{ Exch. $\mathrm{Ca}^{2+}$} & Surface & Exponential* & 91642 & 260984 & 0.35 & Strong & 2767 & 0.935 & 123.4 & 23 \\
\hline & Subsurface & Exponential* & 65328 & 120128 & 0.54 & Strong & 1589 & 0.971 & 165.2 & 24 \\
\hline \multirow[t]{2}{*}{ Exch. $\mathrm{Mg}^{2+}$} & Surface & Exponential* & 1574 & 41995 & 0.04 & Moderate & 1656 & 0.852 & 54.3 & 38 \\
\hline & Subsurface & Exponential* & 26151 & 43836 & 0.60 & Moderate & 2905 & 0.984 & 42.1 & 51 \\
\hline \multirow[t]{2}{*}{$\mathrm{CaCl}_{2}-\mathrm{S}$} & Surface & Spherical* & 234 & 410 & 0.57 & Moderate & 4244 & 0.912 & 0.04 & 38 \\
\hline & Subsurface & Spherical & 92.2 & 133.4 & 0.69 & Moderate & 3141 & 0.955 & 0.03 & 40 \\
\hline \multirow[t]{2}{*}{ HWB } & Surface & Gaussian* & 0.06 & 0.09 & 0.67 & Moderate & 1888 & 0.963 & 0.02 & 60 \\
\hline & Subsurface & Exponential* & 0.13 & 0.24 & 0.54 & Moderate & 1807 & 0.961 & 0.02 & 58 \\
\hline
\end{tabular}

* Transformation for normal distribution.

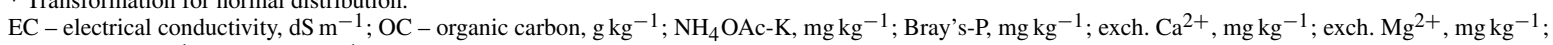

$\mathrm{CaCl}_{2}-\mathrm{S}, \mathrm{mg} \mathrm{kg}^{-1} ; \mathrm{HWB}, \mathrm{mg} \mathrm{kg}^{-1}$; MSE-mean square error; $\mathrm{G}$ - goodness-of-prediction criterium.

ings of Foroughifar et al. (2013) who reported range values of 1600 to $7364 \mathrm{~m}$ for different soil properties of northwest Iran. Several studies also reported different range values of 2.5 to $9.1 \mathrm{~km}$ for DTPA extractable Zn (Behera et al., 2011), 3.30 to $28 \mathrm{~km}$ for DTPA extractable $\mathrm{Cu}$ (Behera et al., 2012), and 0.7 to $66 \mathrm{~km}$ for DTPA extractable Mn and 2.7 to $5.2 \mathrm{~km}$ for DTPA extractable Fe (Behera and Shukla, 2014) in some acid soils of India. According to Kerry and Oliver (2004), the sampling interval should be less than half the semivariogram range. It is therefore recommended that for ensuing studies aimed at characterizing spatial dependency of soil properties in similar areas, soil sampling should be done at distances shorter than the range found in this study.
Cross-validation technique was used to identify the most accurate predictions for soil properties with the lowest MSE values (Table 3). Lowest MSE values indicate that kriging predictions of soil properties are closer to measured values. The accuracy of kriged interpolation maps of soil properties was also measured by the $G$ values (Table 3 ) which varied from 23 (for exchangeable $\mathrm{Ca}^{2+}$ in surface layer) to $60 \%$ (for HWB in surface layer). This is in consistent with the observations made by Mueller et al. (2003) and Tesfahunegn et al. (2011). The $G$ values for the soil properties reveal the prediction capacity of the data sets using kriging from the sample points as compared to average values of the area. Greater than zero $G$ values indicate that kriging is more accurate than 
the average value of the area. For example, the $G$ value of $54 \%$ for soil surface $\mathrm{pH}$ indicates that the kriged $\mathrm{pH}$ map is $54 \%$ more accurate than those achieved using average value of the area. Thus, the use of kriging interpolation technique was appropriate for developing maps of soil properties.

Spatial distribution maps (Fig. 3) of different soil properties revealed that oil palm plantations of the area could be divided into homogenous small zones depending upon the different nutrient ranges. Distribution map of $\mathrm{pH}$ in surface soil layers revealed almost all the area having $\mathrm{pH}$ of 5.00 to 6.00. Low $\mathrm{pH}$ values occurred in southern and south-eastern parts. In subsurface soil layers, low $\mathrm{pH}$ of $<5.00$ occurred in south-eastern part whereas relatively higher $\mathrm{pH}$ prevailed in north-western part. According to Dessai (2011), areas having low $\mathrm{pH}$ values compared to other areas may be due to acidic parent material from which the soil developed and different soil management practices. Soil EC had irregular distribution pattern whereas relatively low values of EC were recorded in north-western parts of both the soil layers. This may be due to sandy loam soil texture and the presence of low OC in north-western part (Bhattacharyya et al., 2013). Higher EC values in other parts of surveyed area probably due to silt loam soil texture with high water table (Pal et al., 2014). Higher amount of soil OC was found to be distributed in the southern and south-eastern parts in surface as well as subsurface soil layers. This may be ascribed to prevalence of higher slope and low rate of SOM mineralization in south-eastern parts compared to other areas. Lower amounts of $\mathrm{NH}_{4} \mathrm{OAc}-\mathrm{K}$ were recorded in western parts in both the soil layers. Higher amount of Bray's-P was found to be distributed in most parts in surface soil layers whereas low amount of Bray's-P occurred in south-western part. Bray's-P distribution was irregular in subsurface soil layers. Build up of $\mathrm{P}$ in surface layers may be due to continuous $\mathrm{P}$ addition and their fixation in soil which is acidic in nature. Exchangeable $\mathrm{Ca}^{2+}$ exhibited irregular distribution pattern in both the soil layers. In surface as well as subsurface soil layers, lower amount of exchangeable $\mathrm{Mg}^{2+}$ was found to be distributed in southern parts as compared to that in northern parts. Irregular distribution pattern of $\mathrm{CaCl}_{2}-\mathrm{S}$ was recorded in surface soil layers whereas low values of $\mathrm{CaCl}_{2}-\mathrm{S}$ were observed in southern part of the study area. Higher amount of HWB was found to be distributed in central part in contrast to low values in north-western and south-eastern part in surface soil layers. Distribution pattern of HWB was irregular in subsurface soil layers. The different distribution variability of the soil properties in oil palm plantations of this area is predominantly due to climate and landscape along with farm practices including application of different quantities of nutrients through fertilizers (Behera et al., 2016). The kriged distribution maps for different soil properties providing quantitative information about soil properties in both the soil layers is of great use for plantation staff, farm managers, extension officers and farmers. This will help in visualizing soil fertility status for planning appropriate strategies for efficient site specific soil nutrient management and variable-rate fertilizer application technology. It leads for obtaining optimum output and oil palm yield which can provide environmentally sustainable maximum return to farmers with optimum input utilization combined with best management practices (Fu et al., 2010; Behera et al., 2012). The areas with low and medium nutrient status require more amount of fertilizer application as compared to areas having high nutrient status. For example, exchangeable $\mathrm{Mg}^{2+}$ status is low in southern part of the area compared to northern part.

\section{Conclusions}

Geostatistical analysis is the key for studying the spatial variability of soil properties for sustainable soil resource management. The mean values of soil properties in surface and subsurface layers of study area were 5.35 and $5.28(\mathrm{pH}), 0.13$ and $0.08 \mathrm{dS} \mathrm{m}^{-1}$ (EC), 19.8 and $13.2 \mathrm{~g} \mathrm{~kg}^{-1}$ (OC), 270 and $199 \mathrm{mg} \mathrm{kg}^{-1}$ ( $\left.\mathrm{NH}_{4} \mathrm{OAc}-\mathrm{K}\right), 24.7$ and $9.78 \mathrm{mg} \mathrm{kg}^{-1}$ (Bray'sP), 914 and $795 \mathrm{mg} \mathrm{kg}^{-1}$ (exchangeable $\mathrm{Ca}^{2+}$ ), 203 and $225 \mathrm{mg} \mathrm{kg}^{-1}$ (exchangeable $\mathrm{Mg}^{2+}$ ), 23.2 and $16.3 \mathrm{mg} \mathrm{kg}^{-1}$ $\left(\mathrm{CaCl}_{2}-\mathrm{S}\right)$ and 0.70 and $0.64 \mathrm{mg} \mathrm{kg}^{-1}$ (HWB), respectively. Studied soil properties had large variability in spatial distribution pattern in both surface and subsurface soil layers of oil palm plantations. Positive and significant correlations were recorded between soil $\mathrm{pH}$ and exchangeable $\mathrm{Ca}^{2+}$, soil $\mathrm{EC}$ and $\mathrm{NH}_{4} \mathrm{OAc}-\mathrm{K}$, Bray's-P and $\mathrm{CaCl}_{2}-\mathrm{S}$ and exchangeable $\mathrm{Ca}^{2+}$ and exchangeable $\mathrm{Mg}^{2+}$ in both the soil layers. Best-fit models of studied soil properties were exponential, Gaussian, stable, K-Bessel and spherical with moderate to strong spatial dependency. The prediction maps generated by geostatistical analysis are useful for site-specific soil nutrient management in oil palm plantations of the area by delineating management zones and adoption of variable fertilizer application strategies.

\section{Data availability}

The data are available in data bank of ICAR-Indian Institute of Oil Palm Research, Pedavegi, West Godavari, Andhra Pradesh, India (http://www.dopr.gov.in). 


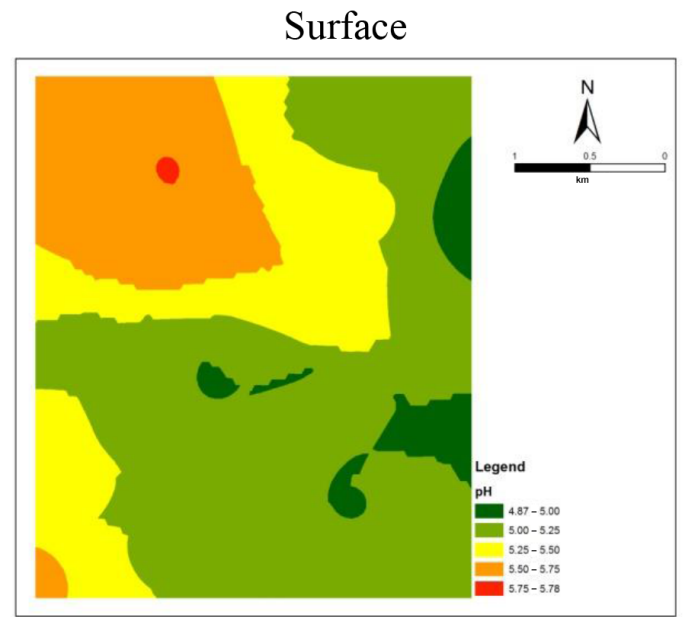

Surface

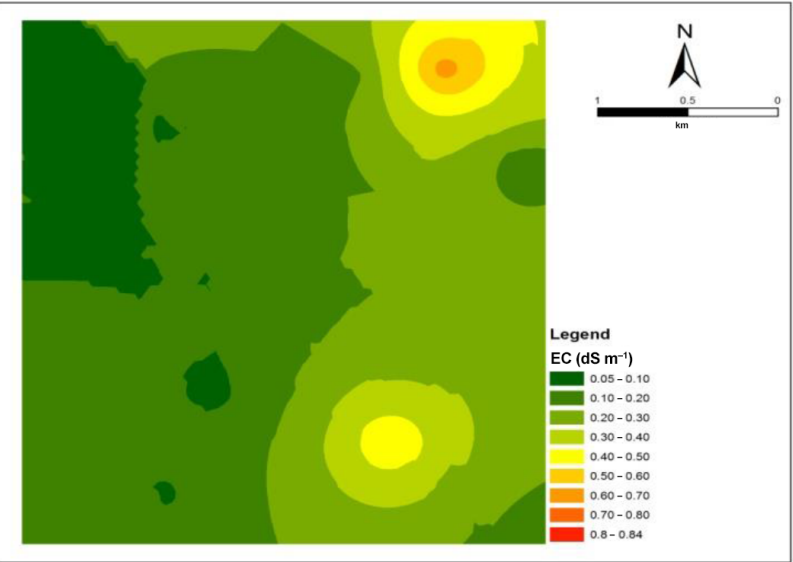

$\mathrm{OC}$

\section{Surface}

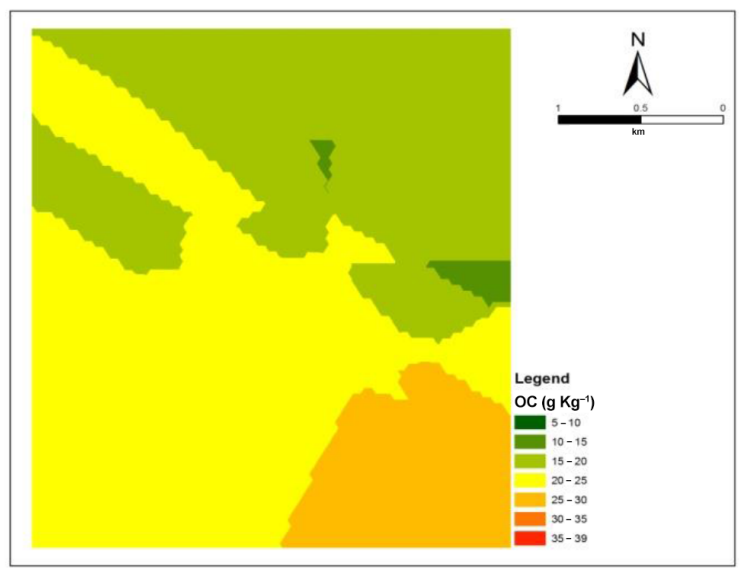

$\mathrm{EC}$
$\mathrm{pH}$
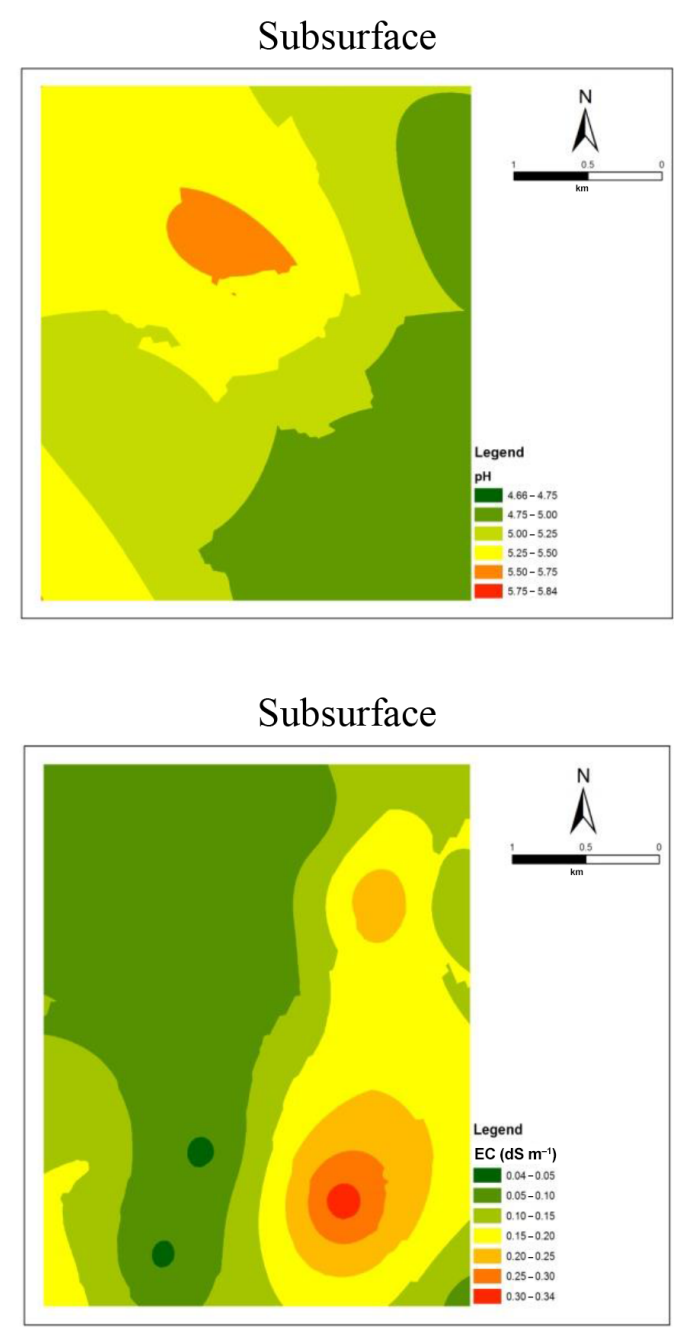

Subsurface

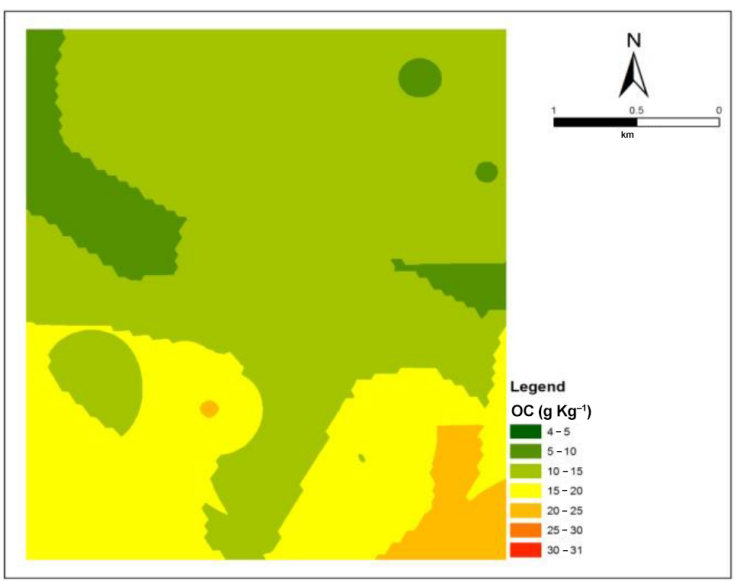

Figure 3. 


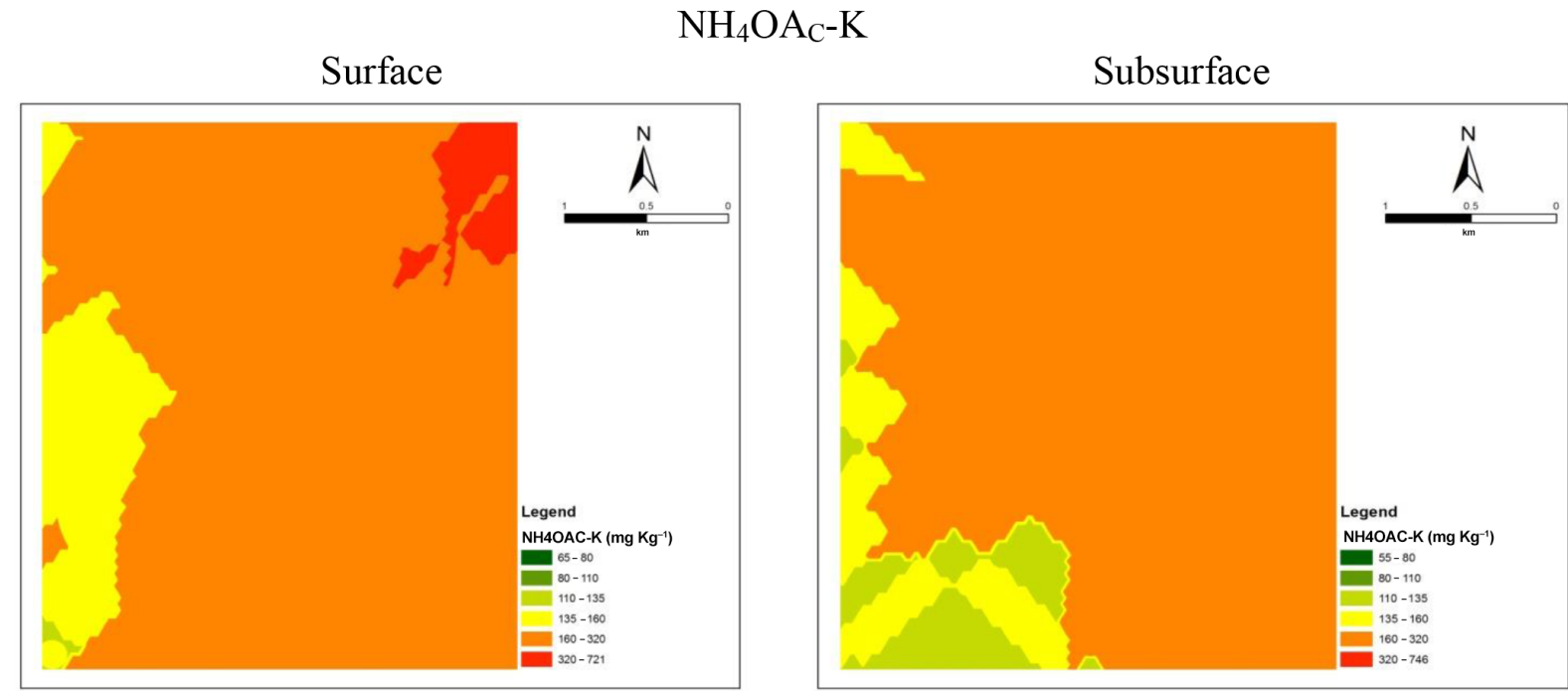

Bray's-P

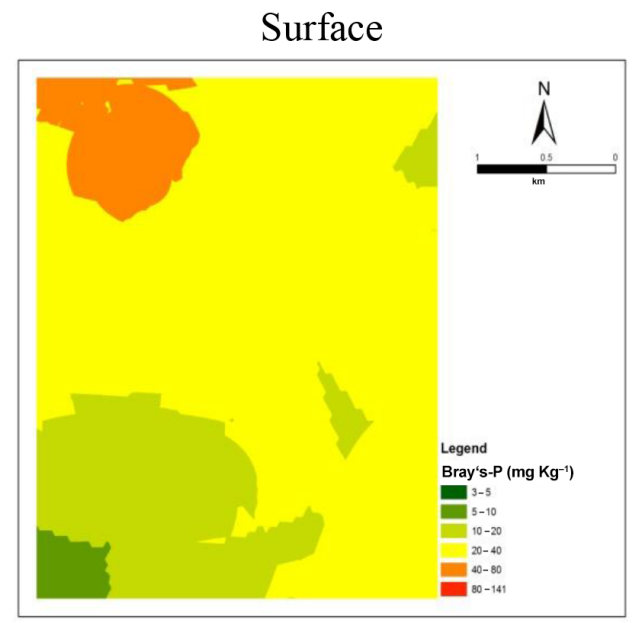

Subsurface

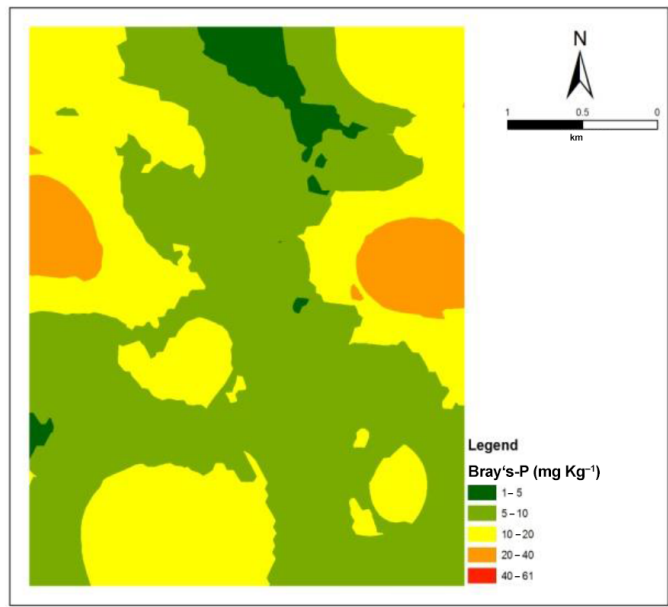

Exch. $\mathrm{Ca}^{2+}$

Surface

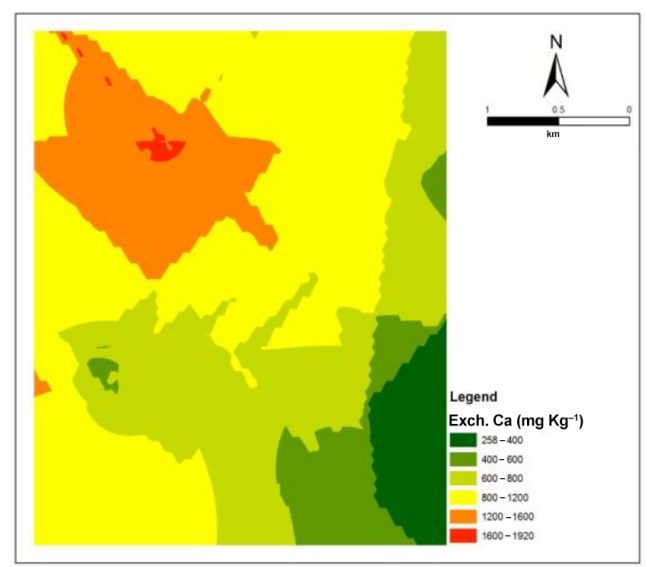

Subsurface

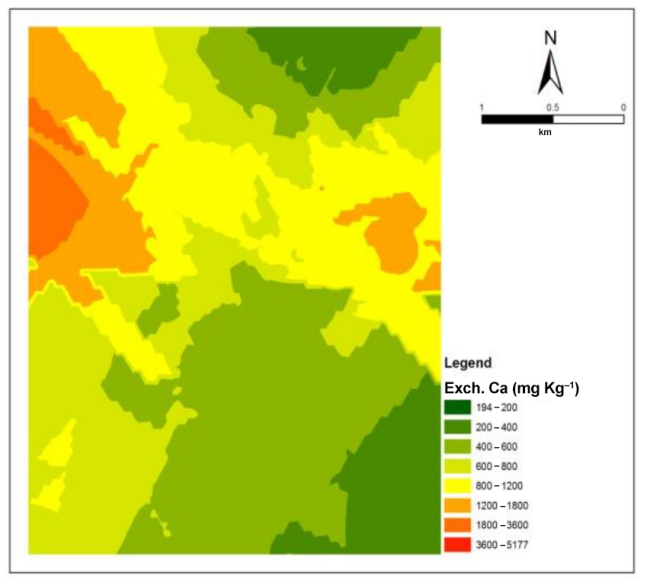

Figure 3. 


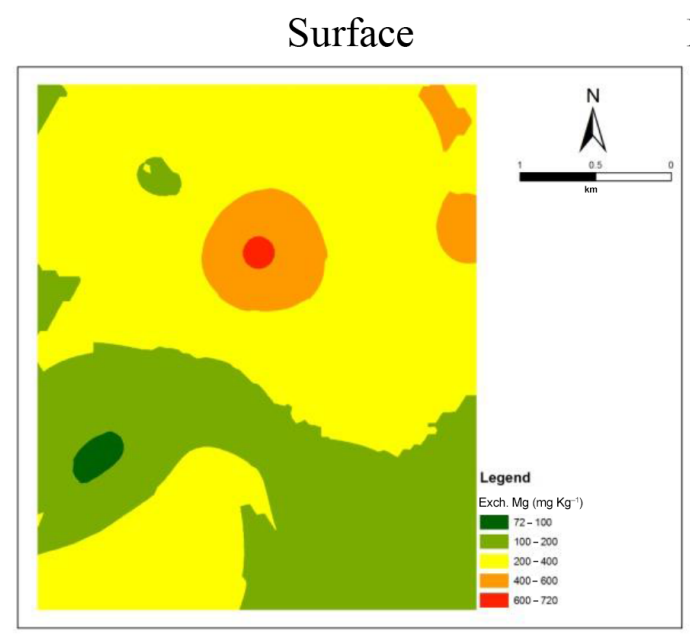

Exch. $\mathrm{Mg}^{2}$

Subsurface

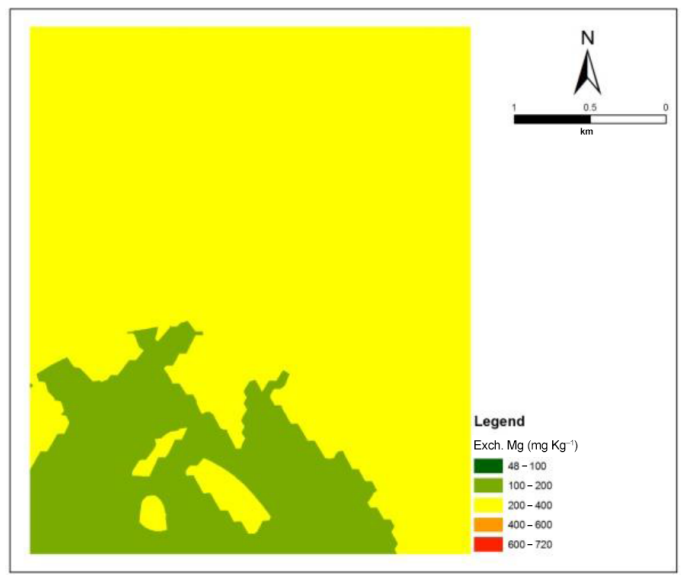

\section{$\mathrm{CaCl}_{2}-\mathrm{S}$}

Surface

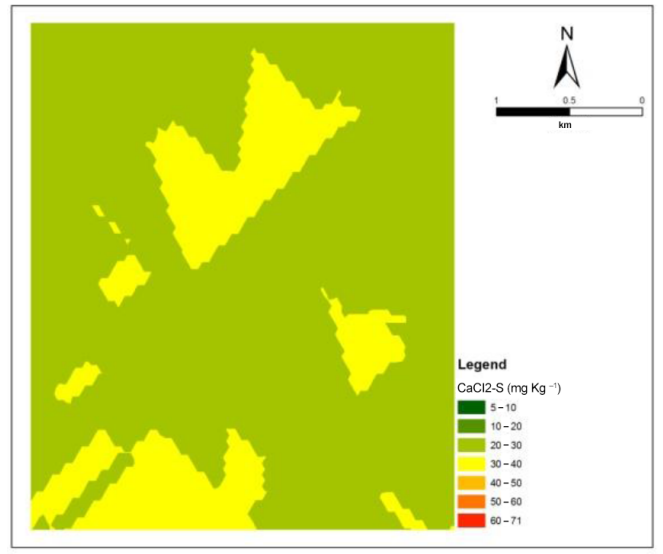

Surface

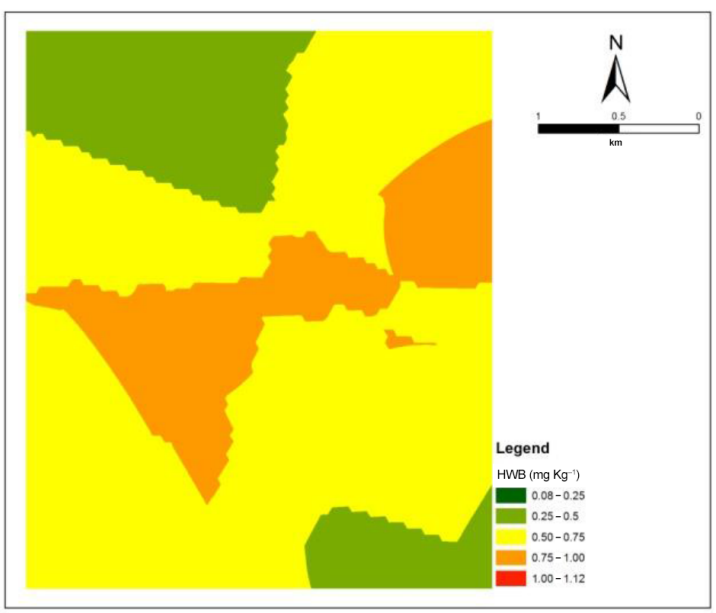

Subsurface

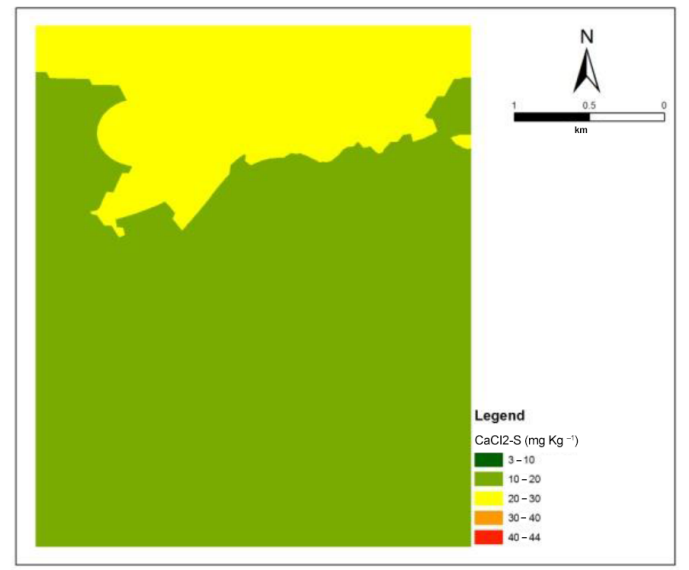

HWB

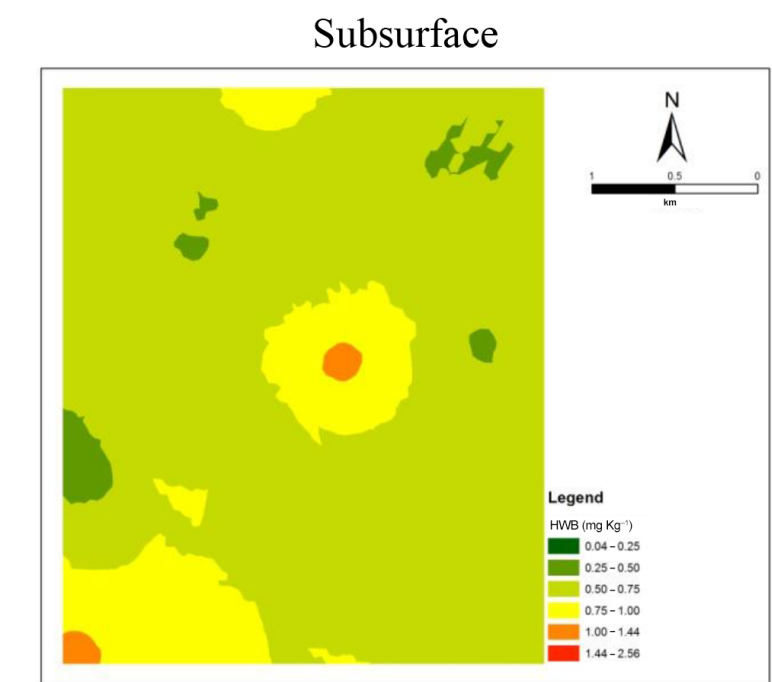

Figure 3. Kriged interpolation maps of soil properties in surface $(0-20 \mathrm{~cm})$ and subsurface $(20-40 \mathrm{~cm})$ soil layers. 
Acknowledgements. The authors gratefully acknowledge the help rendered by M/s Godrej Agrovet Private Limited., India for collection of soil samples. The authors thank Artemi Cerda and the topical editor Paulo Pereira and the anonymous reviewers for their suggestions for improvement of the manuscript.

Edited by: P. Pereira

\section{References}

Agterberg, F. P.: Trend surface analysis, in: Spatial Statistics and Models, edited by: Gaile, G. L. and Willmott, C. J., Reidel, Dordrecht, The Netherlands, 174-171, 1984.

Behera, S. K. and Shukla, A. K.: Depth-wise distribution of zinc, copper, manganese and iron in acid soils of India and their relationship with some soil properties, J. Indian Soc. Soil Sci., 61, 244-252, 2013.

Behera, S. K. and Shukla, A. K.: Total and extractable manganese and iron in some cultivated acid soils of India - status, distribution and relationship with some soil properties, Pedosphere, 24, 196-208, 2014

Behera, S. K. and Shukla, A. K.: Spatial distribution of surface soil acidity, electrical conductivity, soil organic carbon content and exchangeable potassium, calcium and magnesium in some cropped acid soils of India, Land Degrad. Dev., 26, 71-79, 2015.

Behera, S. K., Singh, M. V., Singh, K. N., and Todwal, S.: Distribution variability of total and extractable zinc in cultivated acid soils of India and their relationship with some selected soil properties, Geoderma, 162, 242-250, 2011.

Behera, S. K., Shukla, A. K., and Singh, M. V.: Distribution variability of total and extractable copper in cultivated acid soils of India and their relationship with some selected soil properties, Agrochimica, LVI (1), 28-41, 2012.

Behera, S. K., Suresh, K., Rao, B. N., Manoja, K., and Manorama, K.: Soil nutrient status and leaf nutrient norms in oil palm (Elaeis guineensis Jacq.) plantations grown in the west coastal area of India, Commun. Soil Sci. Plant Anal., 47, 255-262, 2016.

Berendse, F., van Ruijven, J., Jongejans, E., and Keesstra, S.: Loss of plant species diversity reduces soil erosion resistance, Ecosystems, 18, 881-888, 2015.

Bhattacharyya, T., Pal, D. K., Mandal, C., Chandran, P., Ray, S. K., Sarkar, D., Velmourougane, K., Srivastava, A., Sidhu, G. S., Singh, R. S., Sahoo, A. K., Dutta, D., Nair, K. M., Srivastava, R., Tiwary, P., Nagar, A. P., and Nimkhedkar, S. S.: Soils of India: historical perspective, classification and recent advances, Current Sci., 104, 1308-1323, 2013.

Bray, R. H. and Kurtz, L. T.: Determination of total, organic and available forms of phosphorus in soils, Soil Sci., 59, 39-45, 1945.

Brevik, E. C., Cerdà, A., Mataix-Solera, J., Pereg, L., Quinton, J. N., Six, J., and Van Oost, K.: The interdisciplinary nature of SOIL, SOIL, 1, 117-129, doi:10.5194/soil-1-117-2015, 2015.

Brevik, E. C., Calzolari, C., Miller, B. A., Pereira, P., Kabala, C., Baumgarten, A., and Jordan, A.: Soil mapping, classification, and pedologic modeling: History and future directions, Geoderma, 264, Part B, 256-274, 2016.

Cambardella, C. A., Moorman, T. B., Novak, J. M., Parkin, T. B., Karlen, D. L., Turco, R. F., and Konopka, A. E.: Field scale vari- ability of soil properties in central Iowa soils, Soil Sci. Soc. Am. J., 58, 1501-1511, 1994.

Cerda, A., Morera, A. G., and Bodi, M. S.: Soil and water losses from new citrus orchards growing on sloped soils in the western Mediterranean basin, Earth Surf. Proc. Land., 34, 1822-1833, 2009.

Corley, R. H. V. and Tinker, P. B.: The Oil Palm. 4th Edition, Blackwell Sciences Ltd., Oxford, United Kingdom, 2003.

Corwin, D. L. and Lesch, S. M.: Apparent soil electrical conductivity measurements in agriculture, Comp. Electr. Agri., 46, 11-43, 2005.

Decock, C., Lee, J., Necpalova, M., Pereira, E. I. P., Tendall, D. M., and Six, J.: Mitigating $\mathrm{N}_{2} \mathrm{O}$ emissions from soil: from patching leaks to transformative action, SOIL, 1, 687-694, doi:10.5194/soil-1-687-2015, 2015.

Dessai, A. G.: The geology of Goa group: Revisited, J. Geol. Soc. India, 78, 233-242, 2011.

ESRI: ArcGIS Desktop: Release 10.1. Environmental Systems Research Institute, Redlands, CA, 2012.

Fairhurst, T. H., and Mutert, E.: Interpretation and management of oil palm leaf analysis data. Better Crops Intern., 13(1), 48-51, 1999.

Ferreira, V., Panagopoulos, T., Andrade, R., Guerrero, C., and Loures, L.: Spatial variability of soil properties and soil erodibility in the Alqueva reservoir watershed, Solid Earth, 6, 383-392, doi:10.5194/se-6-383-2015, 2015.

Foroughifar, H., Pakpour, A., Jafarzadeh, A. A., Miransari, M., and Torabi, H.: Using geostatistics and geographic information system techniques to characterize spatial variability of soil properties, including micronutrients, Commun. Soil Sci. Plant Anal., 44, 1273-1281, 2013.

Foth, H. D. and Turk, L. M.: Fundamentals in Soil Science, John Wiley, New York, 1972.

Franzlubbers, A. J. and Hons, F. M.: Soil profile distribution of primary and secondary plant-available nutrients under conventional and no tillage, Soil Till. Res., 39, 229-239, 1996.

Fu, W., Tunney, H., and Zhang, C.: Spatial variation of soil nutrients in a dairy farm and its implications for site-speci?c fertilizer application, Soil Till. Res., 106, 185-193, 2010.

Goh, K. J., Hardter, R., and Fairhust, T. H.: Fertilizer for maximum return, in Oil palm: Management for High and Sustainable Yields, edited by: Fairhust, T. H., and Hardter, R., International Potash Institute, Singapore, 279-306, 2003.

Goovaerts, P.: Geostatistics for natural resources evaluation, Oxford Univ. Press, New York, 1997.

Goovaerts, P.: Geostatistical tools for characterizing the spatial variability of microbiological and physio-chemical soil properties, Biol. Fert. Soils, 27, 315-334, 1998.

Gupta, U. C.: A simplified method for determining hot-water soluble boron in podzol soils, Soil Sci., 103, 424-428, 1967.

Hanway, J. J. and Heidel, H.: Soil analyses methods as used in Iowa state college soil testing laboratory, Iowa Agriculture, 57, 1-31, 1952.

Jackson, M. L.: Soil Chemical Analysis, Prentice Hall of India, New Delhi, 1973.

Johnston, M., Foley, J. A., Holloway, T., Kucharik, C. J., and Monfreda, C.: Resetting global expectations from biofuels, Environ. Res. Lett., 4, 014004, doi:10.1088/1748-9326/4/1/014004, 2009. 
Jones, Jr. J. B.: Soil test methods: Past, present, and future, Commun. Soil Sci. Plant Anal., 29, 1543-1552, 1998.

Keesstra, S. D., Geissen, V., Mosse, K., Piiranen, S., Scudiero, E., Leistra, M., and van Schaik, L.: Soil as a filter for groundwater quality, Current Opinion Env. Sust., 4, 507-516, 2012.

Kerry, R. and Oliver, M. A.: Average variograms to guide soil sampling for land management, Int. J. Appl. Earth Obs., 5, 307-325, 2004.

Kerry, R. and Oliver, M. A.: Comparing sampling needs for variograms of soil properties computed by the method of moments and residual maximum likelihood, Geoderma, 140, 383-396, 2007.

Lieskovský, J. and Kenderessy, P.: Modelling the effect of vegetation cover and different tillage practices on soil erosion in vineyards: a case study in vráble (Slovakia) using WATEM/SEDEM, Land Degrad. Dev., 25, 288-296, 2014.

Lopez-Granados, F., Jurado-Exposito, M., Atenciano, S., GarciaFerrer, A., De la Orden, M.S., and Garcia-Torres, L.: Spatial variability of agricultural soil parameters in southern Spain, Plant Soil, 246, 97-105, 2002.

McCormick, S., Jordan, C., and Bailey, J. S.: Within and betweenfield spatial variation in soil phosphorus in permanent grassland, Precis. Agric., 10, 262-276, 2009.

McLaughlin, M. J., Reuter, D., and Rayment, G. E.: Soil testingPrinciples and concepts, in: Soil Analysis: An Interpretation Manual, edited by: Perverill, K. I., Sparrow, L. A., and Reuter, D. J., CSIRO publishing, Collingwood, 1-21, 1999.

Mengel, K. and Kirkby, E. A.: Principles of Plant Nutrition, International Potash Institute, Basel, Switzerland, 1987.

Misdorp, R.: Existing problems in the coastal zones: A concern for the IPCC? In Changing climate and the coast: Report to the IPCC from the Miami conference on adaptive responses to sea level rise and other impacts of global climate change, Proceedings of the Miami Workshop, 1990.

Mueller, T. G., Hartsock, N. J., Stombaugh, T. S., Shearer, S. A., Cornelius, P. L., and Barnhise, R. I.: Soil electrical conductivity map variability in limestone soil overlain by loess, Agron. J., 95, 496-507, 2003.

Mukherjee, A., Zimmerman, A. R., Hamdan, R., and Cooper, W. T.: Physicochemical changes in pyrogenic organic matter (biochar) after 15 months of field aging, Solid Earth, 5, 693-704, doi:10.5194/se-5-693-2014, 2014.

Mupenzi, J. D. L. P., Li, L., Ge, J., Varenyam, A., Habiyaremye, G., Theoneste, N., and Emmanuel, K.: Assessment of soil degradation and chemical compositions in Rwandan tea-growing areas, Geosci. Front., 2, 599-607, 2011.

Murphy, D. J.: Oil palm: future prospects for yield and quality improvements, Lipid Tech., 21, 257-260, 2009.

Narasimha Rao, B., Suresh, K., Behera, S. K., Ramachandrudu, K., and Manorama, K.: Nutrient management in oil palm, Technical Bulletin, DOPR, Pedavegi, Andhra Pradesh, India, 1-24, 2014.

Ng, S. K. and Thamboo, S.: Nutrient contents of oil palms in Malaya. I. Nutrients required for reproduction: Fruit bunches and male inflorescence, Malaysian Agr. J., 46, 3-45, 1967.

Novara, A., Gristina, L., Guaitoli, F., Santoro, A., and Cerdà, A.: Managing soil nitrate with cover crops and buffer strips in Sicilian vineyards, Solid Earth, 4, 255-262, doi:10.5194/se-4-2552013, 2013.
Novara, A., Rühl, J., La Mantia, T., Gristina, L., La Bella, S., and Tuttolomondo, T.: Litter contribution to soil organic carbon in the processes of agriculture abandon, Solid Earth, 6, 425-432, doi:10.5194/se-6-425-2015, 2015.

Ochoa-Cueva, P., Fries, A., Montesinos, P., Rodríguez-Díaz, J. A., and Boll, J.: Spatial estimation of soil erosion risk by land-cover change in the Andes of southern Ecuador, Land Degrad. Dev., 26, 565-573, 2015.

Oliver, M. A. and Webster, R.: A tutorial guide to geostatistics: Computing and modelling variograms and kriging, Catena, 113, 56-79, 2014.

Pal, D. K., Wani, S. P., Sahrawat, K. L., and Srivastava, P.: Red ferruginous soils of tropical Indian environments: A review of the pedogenic processes and its implications for edaphology, Catena, 121, 260-278, 2014.

Parfitt, J. M. B., Timm, L. C., Pauletto, E. A., Sousa, R. O., Castilhos, D. D., de Avila, C. L., and Reckziegel, N. L.: Spatial variability of the chemical, physical and biological properties in lowland cultivated with irrigated rice, Revista Brasileira de Ciência do Solo (in Portuguese), 33, 819-830, 2009.

Parras-Alcántara, L., Lozano-García, B., Brevik, E. C., and Cerdá, A.: Soil organic carbon stocks assessment in Mediterranean natural areas: A comparison of entire soil profiles and soil control sections, J. Environ. Manag., 155, 219-228, 2015.

Pereira, P., Cerdà, A., Úbeda, X., Mataix-Solera, J., Martin, D., Jordán, A., and Burguet, M.: Spatial models for monitoring the spatio-temporal evolution of ashes after fire - a case study of a burnt grassland in Lithuania, Solid Earth, 4, 153-165, doi:10.5194/se-4-153-2013, 2013.

Pereira, P., Cerdà, A., Úbeda, X., Mataix-Solera, J., Arcenegui, V., and Zavala, L. M.: Modelling the Impacts of Wildfire on Ash Thickness in a Short-Term Period, Land Degrad. Dev., 26, 180192, 2015.

Prasad, M. V., Sarkar, A., and Jameema, J.: Performance of oil palm production technologies, Indian Res. J. Extn. Edn., 10, 10-15, 2013.

Saito, H., McKenna, A., Zimmerman, D. A., and Coburn, T. C.: Geostatistical interpolation of object counts collected from multiple strip transects: ordinary kriging versus finite domain kriging, Stoch. Env. Res. Risk Asst., 19, 71-85, 2005.

Sanil Kumar, V., Pathak, K. C., Pednekar, P., Raju, N. S. N., and Gowthaman, R.: Coastal Processes along the Indian coastline, Curr. Sci., 91, 530-536, 2006.

SAS Institute: The SAS system for Windows, Release 9.2. SAS Inst., Cary, NC, 2011.

Seutloali, K. E. and Beckedahl, H. R.: Understanding the factors influencing rill erosion on roadcuts in the south eastern region of South Africa, Solid Earth, 6, 633-641, doi:10.5194/se-6-6332015, 2015.

Shapiro, S. S. and Wilk, M. B.: An analysis of variance test for normality: complete samples, Biometrika, 52, 591-611, 1965.

Sharma, B. D., Mukhopadhyay, S. S., and Arora, H.: Total and DTPA-extractable micronutrients in relation to pedogenesis in some Alfisols of Punjab, India, Soil Sci., 170, 559-572, 2005.

Smith, F. W. and Loneragan, J. F.: Interpretation of plant analysis: concepts and principles, in: Plant Analysis: An Interpretation Manual, edited by: Reuter, D. J. and Robinson, B., CSIRO Publishing, Collingwood, 3-33, 1997. 
Smith, P., Cotrufo, M. F., Rumpel, C., Paustian, K., Kuikman, P. J., Elliott, J. A., McDowell, R., Griffiths, R. I., Asakawa, S., Bustamante, M., House, J. I., Sobocká, J., Harper, R., Pan, G., West, P. C., Gerber, J. S., Clark, J. M., Adhya, T., Scholes, R. J., and Scholes, M. C.: Biogeochemical cycles and biodiversity as key drivers of ecosystem services provided by soils, SOIL, 1, 665685, doi:10.5194/soil-1-665-2015, 2015.

Soil Survey Staff.: Keys to Soil Taxonomy, 12th Edn., USDANatural Resources Conservation Service, Washington, DC, 2014.

Srinivasarao, C., Venkateswarlu, B., Lal, R., Singh, A. K., Kundu, S., Vittal, K. P. R., Patel, J. J., and Patel, M. M.: Long-term manuring and fertilizer effects on depletion of soil organic carbon stocks under pearl millet-cluster bean-castor rotation in Western India, Land Degrad. Dev., 25, 173-183, 2014.

Stanchi, S., Falsone, G., and Bonifacio, E.: Soil aggregation, erodibility, and erosion rates in mountain soils (NW Alps, Italy), Solid Earth, 6, 403-414, doi:10.5194/se-6-403-2015, 2015.

Tesfahunegn, G. B., Tamene, L., and Vlek, P. L. G.: Catchmentscale spatial variability of soil properties and implications on site-specific soil management in northern Ethiopia, Soil Till. Res., 117, 124-139, 2011.
Utset, A., Lopez, T., and Diaz, M.: A comparison of soil maps, kriging and a combined method for spatially prediction bulk density and field capacity of Ferralsols in the Havana-Matanaz Plain, Geoderma, 96, 199-213, 2000.

Walkley, A. J. and Black, I. A.: An examination of the Degtjareff method for determining soil organic matter and a proposed modification of the chromic acid titration method, Soil Sci., 37, 2938, 1934.

Williams, C. H. and Steinbergs, A.: Soil sulphur fractions as chemical indices of available sulphur in some Australian soils, Australian J. Agri. Res., 10, 340-352, 1969.

Zhang, H., Zhuang, S., Qian, H., Wang, F., and Ji, H.: Spatial variability of the topsoil organic carbon in the Moso bamboo forests of southern China in association with soil properties, PLoS ONE, 10, e0119175, doi:10.1371/journal.pone.0119175, 2015. 